\title{
Scenario planning during rapid ecological change: lessons and perspectives from workshops with southwest Yukon wildlife managers
}

\author{
Dylan M. Beach ${ }^{1}$ and Douglas A. Clark ${ }^{1}$
}

\begin{abstract}
Scenario planning has been increasingly advocated as a strategic planning tool for enabling natural resource managers to make decisions in the face of uncertainty and rapid change. However, few examples exist that discuss the technique's application in that field. We used a scenario planning approach to develop wildlife management goals and evaluated participants' perceptions of scenario planning as a goal development tool. Study participants emphasized the context-specificity of management goals, and that "no-regrets" management strategies might not be constructive. We found that scenario planning can help resource managers identify needs that have been overlooked but may become important in the future. Scenarios can likely be used to develop management goals for other resources within the same system. Scenario planning provides a way to apply traditional ecological knowledge and local knowledge in a planning process in a respectful manner. Further process-oriented findings may be helpful to practitioners or researchers considering this approach: workshops should to be temporally close together for participants to retain context during the process, and ensuring continuity of workshop participants is important. Study participants judged scenario planning to be an effective tool to stimulate group-thought on longer time scales, facilitate adaptive learning, and enhance institutional linkages. Ultimately such outcomes can help groups comprising diverse participants to develop shared mental models of the future and identify pathways to achieve them.
\end{abstract}

Key Words: Champagne \& Aishihik First Nations; change; participatory; qualitative; scenario planning; social-ecological system (SES); wildlife management; Yukon Territory

\section{INTRODUCTION}

Conventional environmental management planning approaches are decreasingly likely to meet their intended goals under conditions of rapid ecological or social change (Berkes et al. 2003, Kay 2008, Chapin et al. 2009, Kofinas 2009). Linked socialecological systems (SESs; Berkes et al. 1998) are characterized by feedbacks and complex, unpredictable phenomena, often thwarting the effective use of linear projections based on current trends (Wollenberg et al. 2000, Carpenter 2002, Peterson et al. 2003a). Creative processes for anticipating change, such as scenario planning, have been proposed as useful alternatives to conventional planning approaches that fail when confronted with surprise (Wollenberg et al. 2000, Alcamo et al. 2005).

Scenarios can take many different forms, depending on the chosen approach (Wollenberg et al. 2000, Alcamo and Henrichs 2008). An important limitation to quantitative scenarios is that mathematical models can only capture a portion of the complex interactions of driving forces inherent in an SES (Alcamo et al. 2005, Alcamo 2008). Quantified scenarios based on mathematical models can be good for simulating well-understood systems over sufficiently short times. However, exclusively quantitative scenarios are typically a poor representation of complex SESs (Swart et al. 2004).

Participatory, qualitative approaches that involve local stakeholders can result in detailed, imaginative, and wide-ranging scenarios (Reed et al. 2013). Involving people to develop scenarios can bring forth more ideas of possible futures that come from outside of the decision-making or management framework (Schoemaker 1995). This helps to address the core problem with decision making of a narrow paradigmatic lens, aiding people to see decisions without the weight of habituated goals and pressures
(Chermack 2004). The involvement of stakeholders in the creation of scenarios can improve decision making (Palomo et al. 2011), because decisions identified and developed by local stakeholders are more likely to be consistent with local priorities, norms, and institutions (Chapin et al. 2006, Walz et al. 2007, Reed et al. 2013).

The purpose of our research was to assess the efficacy and utility of scenario planning by using it to identify wildlife management goals in a rapidly changing social-ecological system. Scenario planning is promoted in the social-ecological systems literature as a planning and decision-making tool when dealing with uncertainty in dynamic SESs (Walker et al. 2002, 2004, Peterson et al. 2003a, Folke 2006, Peterson 2007). We add to the emerging SES literature that appraises the method in practice (e.g., Peterson et al. 2003b, Bohensky et al. 2006, González et al. 2008, Gibon et al. 2010, Palomo et al. 2011, Malinga et al. 2013, PalaciosAgundez et al. 2013, Reed et al. 2013). However, ours is the first study to use scenario planning for wildlife management goal development.

Our study area, the southwest Yukon Territory, Canada, offers ideal prospects for applying scenario planning within a systemsthinking framework. This region has a long history of profound social, economic, and ecological changes that continue (e.g., Slocombe 2001, Cruikshank 2005). Of greatest significance here is the appearance of newly introduced or reintroduced species on the landscape. Within the past 50 years, wood bison (Bison bison athabascae)were reintroduced and elk (Cervus canadensis) were introduced into the territory. Mule deer (Odocoileus hemionus) are increasingly moving northward from British Columbia. The southwest Yukon also has a history of well-established resource comanagement regimes, underpinned by settled Aboriginal land 
claims (Clark and Slocombe 2009). Further, local stakeholders clearly see the need for resource management institutions to have high adaptive capacity (Ogden and Innes 2009).

\section{Scenario planning in environmental management}

Scenario planning considers multiple plausible futures with uncontrollable variables and high uncertainties. It links past and present events with hypothetical courses that examine the relationships of driving forces. It has a goal of creating more robust planning for events that may be unpredictable (Peterson et al. 2003a, Ralston and Wilson 2006, Weeks et al. 2011). It shifts the analytical focus of estimating what is most likely to occur, which is common of predictions or forecasting, toward questions of what are the consequences and most appropriate responses under different circumstances (Duinker and Greig 2007). Scenarios can spur action in the face of uncertainty by using realistic narratives to bring alternative possibilities to life (Carpenter 2002).

The adaptation of scenario planning to conservation and management is fairly recent (Peterson et al. 2003a). It has gained traction as a tool to visualize future climate change and sustainable development implications. Climate scenarios, for example, represent possible future climates developed to determine the impacts of climate change (Beaumont et al. 2008). Many studies discuss possible species' distributions under different climate scenarios based on global climate models (see Fuller et al. 2008, Jensen et al. 2008, Maiorano et al. 2011, Rose and Burton 2011). Other studies have been used to help engage local stakeholders to envision how climate change might impact their communities (see Sheppard et al. 2011). Several global environmental assessment exercises have included a scenario component to help visualize future environmental challenges (see IPCC 2000, UNEP 2007 and MEA 2005).

Effective scenarios should be developed within a systems thinking framework (Chermack et al. 2001) where interacting forces are examined and not just trends and uncertainties (Schoemaker 1995). The focus on the relationships of driving forces is significant because small, persistent forces can alter species interactions, destabilize communities, and drive major biome shifts (Parmesan and Yohe 2003). Once the interactions between forces are highlighted, participants can develop a broader understanding of the SES and how management might build resilience of the system. A scenario planning process can help decision makers visualize plausible future stability domains for a given SES and develop policies to direct the SES to a desired future scenario. By utilizing knowledge about the local SES function from stakeholders who live in the study area, scenarios can capture change in specific functions of the SES (Kok et al. 2004, Gibon et al. 2010). Conceptualizing different futures can help wildlife managers recognize changes, make decisions, and adjust policies to shift the system toward a future that accomplishes a range of management objectives (Peterson et al. 2003a, Weeks et al. 2011).

\section{METHODS}

Participants and their selection of planning parameters

Originally the study was intended to focus exclusively on wood bison, and all members of the Yukon Wood Bison Technical Team were invited to the first workshop. During that workshop participants suggested and agreed to incorporate elk and mule deer into the study. Members of the Yukon Elk Management Planning Team were thus invited to participate in the subsequent workshops. There is no committee responsible for mule deer management. Those two planning teams comprise representatives from Environment Yukon, Environment Canada, affected First Nations, and affected Renewable Resources Councils. They also receive input and have representatives from interest groups such as the Yukon Agriculture Association, the Yukon Fish and Game Association, and the Yukon Outfitters Association. Demographic and professional characteristics of study participants are described in Table 1.

Table 1. Participant demographics and affiliations.

\begin{tabular}{lllcc}
\hline $\begin{array}{l}\text { Respondent } \\
\text { ID }\end{array}$ & Gender & Community & First Nation & $\begin{array}{c}\text { Workshops } \\
\text { attended }\end{array}$ \\
\hline 1 & Female & Champagne & Yes & 1,2 \\
2 & Male & Mayo & No & 1,2 \\
3 & Male & Whitehorse & No & $1,2,3$ \\
4 & Male & Whitehorse & No & 1,2 \\
5 & Male & Haines Junction & No & 1,2 \\
6 & Female & Haines Junction & Yes & $1,2,3$ \\
7 & Male & Haines Junction & No & 2 \\
8 & Female & Whitehorse & Yes & 3 \\
9 & Male & Whitehorse & Yes & 3 \\
10 & Male & Carmacks & No & $1,2,3$ \\
11 & Female & Mendenhall & No & 1,2 \\
12 & Female & Whitehorse & No & 1,3 \\
13 & Male & Champagne & Yes & 1 \\
14 & Male & Haines Junction & No & 1 \\
15 & Male & Haines Junction & No & 1 \\
\hline
\end{tabular}

\section{Scenario development process}

We followed the process described by Ralston and Wilson (2006) to guide scenario development, adapted to fit our particular context (Beach 2014). Scenario planning typically occurs over a series of workshops, which are common venues in northern North America for communicative and collaborative processes (Huntington et al. 2002). Ralston and Wilson (2006) recommend a project that has three workshops of 2-3 days each, with a scenario team of 8-12 participants, and spans 3-4 months (Ralston and Wilson 2006). Three workshops were conducted in Haines Junction, Yukon Territory over a 13-month period. Workshop 1 had nine participants and lasted one day in January 2012, focusing on identifying drivers of change. Workshop 2 lasted two days in April 2012 and nine participants attended, developing the scenario narratives. Two participants from the first workshop did not attend the second workshop, but two participants joined who were not present at the first workshop. Workshop 3 happened over a single day in February 2013 and had six participants, considering and examining possible management responses to the scenarios. Seven participants who had attended previous workshops failed to attend the third workshop. Two individuals who had attended no previous workshops attended the third workshop.

Workshops were facilitated by the second author, whose professional and research relationships in the region predated this 
Table 2. Drivers of change listed alphabetically and grouped by axis of uncertainty.

\begin{tabular}{|c|c|c|}
\hline Changing Ecological-Social Interactions & Land Use & The Human Factor \\
\hline $\begin{array}{c}\text { Changing Water } \\
\text { Climate Change } \\
\text { Country Food } \\
\text { Culturally Sensitive Species } \\
\text { Food Security } \\
\text { Hunter Patterns } \\
\text { Hunting Values } \\
\text { Insects } \\
\text { Invasive Species } \\
\text { Loss of Caribou } \\
\text { Meadows } \\
\text { Moose } \\
\text { Parasites and Diseases } \\
\text { Predation - Bear, Wolf, Cougar, and others } \\
\text { Repetitive Fire } \\
\text { Shakat - Lifestlye Calendar } \\
\text { Species Shifts } \\
\text { Treeline }\end{array}$ & $\begin{array}{c}\text { Access } \\
\text { Agriculture } \\
\text { Business Opportunity } \\
\text { Electricity Projects } \\
\text { Exploration } \\
\text { Forestry } \\
\text { Free Land } \\
\text { Global Economy } \\
\text { Human Development on Landscape } \\
\text { Infrastructure } \\
\text { Land-Use Planning } \\
\text { Local Development } \\
\text { Markets } \\
\text { Mining } \\
\text { Natural Resource Demand - Gold, Copper } \\
\text { Production } \\
\text { Protected Areas } \\
\text { Sprawl } \\
\text { Technology } \\
\text { Traffic Patterns/Density }\end{array}$ & $\begin{array}{c}\text { Affluence } \\
\text { Attitudes and Values } \\
\text { Laws } \\
\text { Lifestyle } \\
\text { Open Regulatory Regime } \\
\text { Regulations } \\
\text { Teaching } \\
\text { Yukon Territory Demographics }\end{array}$ \\
\hline
\end{tabular}

study by 12 years. Flip charts were used to record main ideas of conversation threads and to facilitate specific steps of the scenario development process. Workshops were audio recorded to capture all participant input. We used these recordings to evaluate and include input when writing the scenarios. The recordings also helped us reattach context to participant input, such as the tone of voice. Audio was especially helpful for triangulating between workshop discussion, field notes, and flip charts.

Within the area of interest participants defined the specific study area as bounded by Haines Junction, Whitehorse, Carmacks, and Kluane Lake (Fig. 1). This area roughly coincides with the Aishihik Wood Bison Herd range as well as Champagne \& Aishihik First Nations' traditional territory. The study site is characterized as an interior dry forest dominated by white spruce with aspen and willow. It is within the Ruby Ranges ecoregion within the boreal cordillera ecozone (Smith et al. 2004). Participants selected 20 years (2032) as a temporal reference point because it is approximately a generation, and bison have been on the landscape for about that amount of time. Visually representing themes and local conditions enhances people's ability to visualize different futures, allowing people to more readily think about the implications of a given scenario (Ralston and Wilson 2006, Vervoort et al. 2010, Sheppard et al.2011). Consequently, we hired a Yukon-based graphic artist to create a set of four computergenerated images (one for each scenario), each representing main themes and important drivers (Fig. 2).

\section{Understanding participants' perspectives}

Two surveys were completed by participants, one after the second workshop and one after the third workshop. These surveys asked questions about perceptions of scenario planning as a tool to develop wildlife management goals. Because the number of completed surveys was small $(n=8$ for survey 1 and $n=6$ for survey 2), survey data was amalgamated, and coded and analyzed by hand. Researchers also kept field notes during workshops. These notes included important participant commentary, further research ideas, emerging themes, and tone of participant interactions. All methods used were approved by the University of Saskatchewan's Behavioral Research Ethics Board, and this research was carried out under the authority of annually issued Yukon Scientists and Explorers Act Licenses.

Fig. 1. Study site. Southwest Yukon bounded by Whitehorse, Haines Junction, Kluane Lake, and Carmacks (Google Earth 2012).

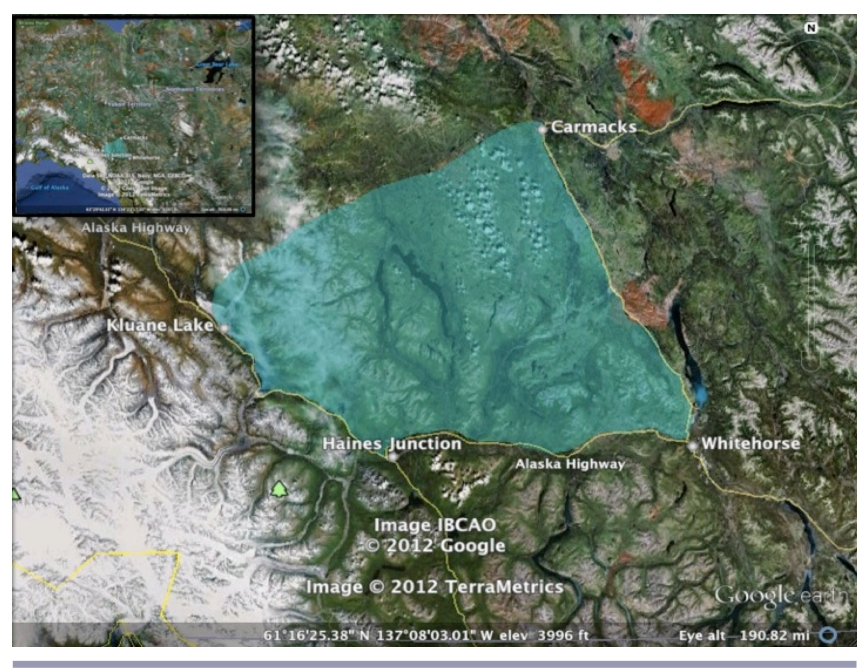

\section{RESULTS}

\section{Scenario development process}

Axis logics

The scenario team identified 46 drivers of change and then grouped these into three distinct axes of uncertainty (Table 2). Eighteen drivers were grouped into a "Changing Ecological- 
Fig. 2. Illustrations of the four scenarios, highlighting major themes and events within each. Full scenario narratives can be found in Appendix 1.
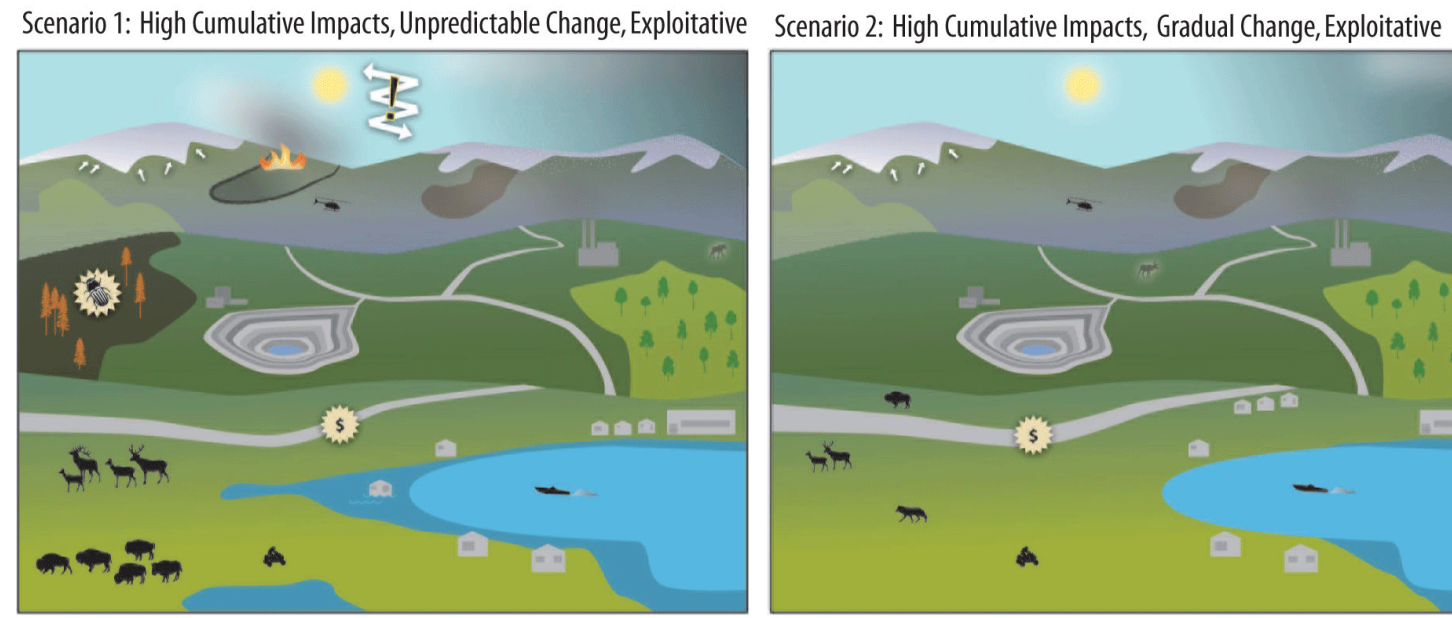

Scenario 3: Low Cumulative Impacts, Unpredictable Change, Stewardship
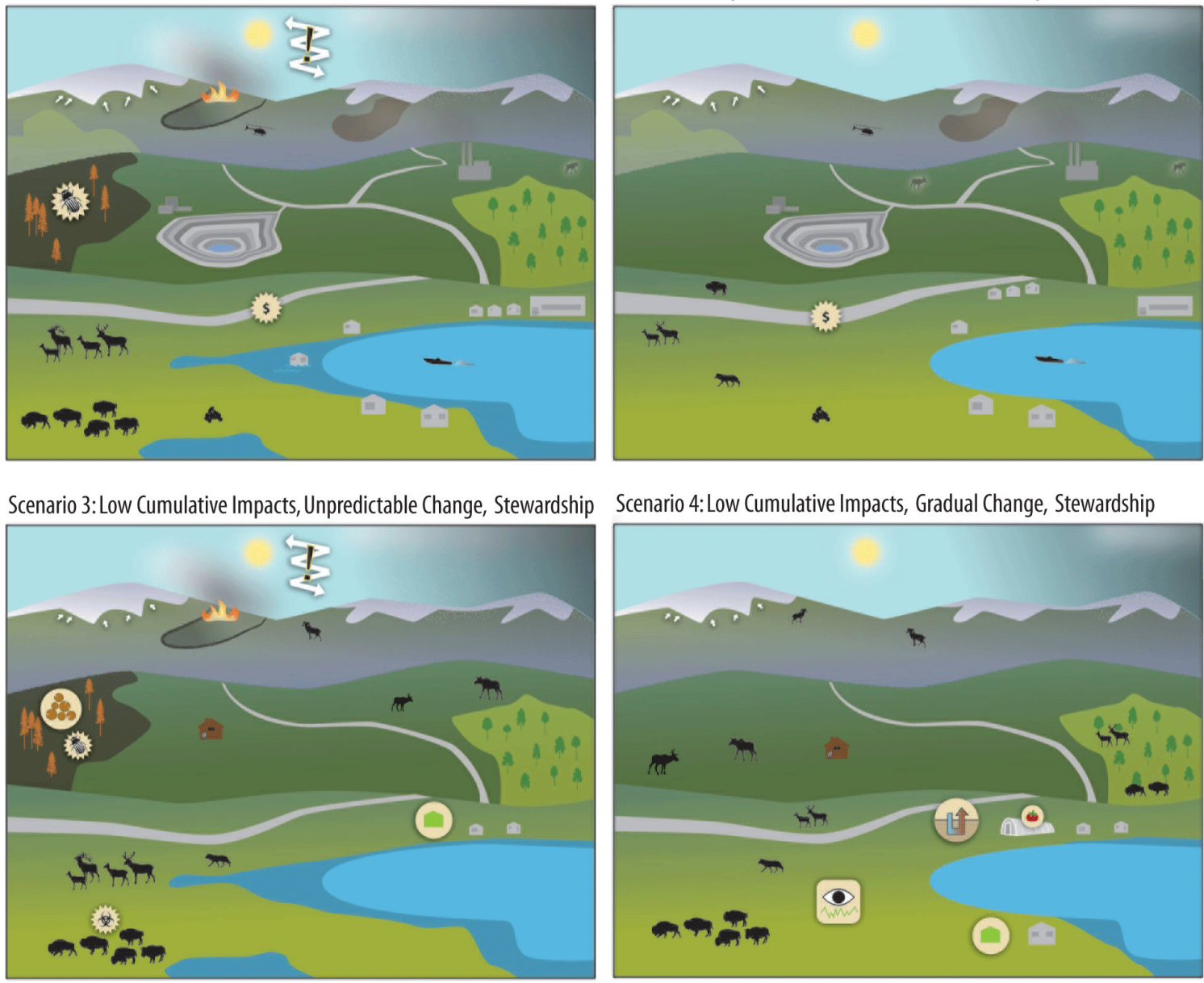

Scenario 4:Low Cumulative Impacts, Gradual Change, Stewardship

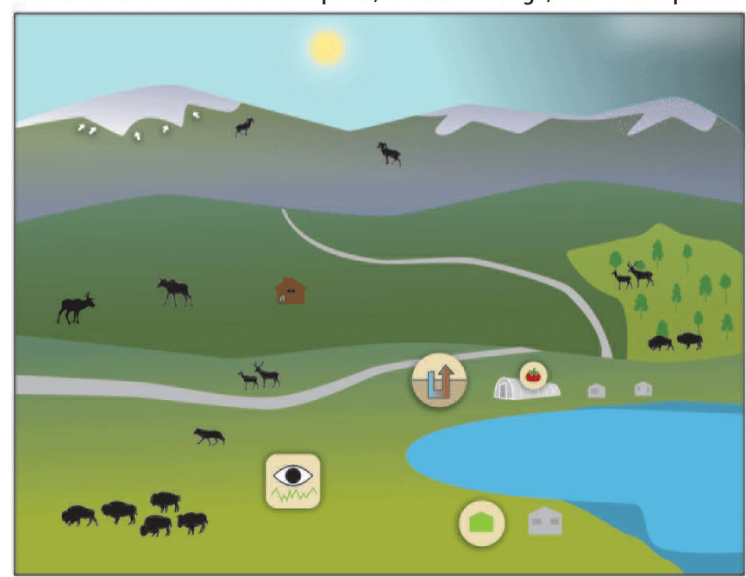

Legend

= Selective Harvesting
$=$ Sustainable Building
= Beetle Kill

(4) = Geothermal Heating/Cooling

s = Pricey Road Expansion/Repairs

(๘) Organic Greenhouse

1 = Highly Unpredictable Weather

- Landscape Monitoring

2. Disease

Social Interactions" axis. Twenty drivers were grouped into a "Land Use" axis. Eight drivers were grouped into "The Human Factor" axis. Once axes were selected, participants identified the logics for the axes: the two polar directions an axis could manifest in the future. The "Changing Ecological-Social Interactions" axis had logics of "unpredictable change" and "gradual change." The "Land Use" axis had logics of "high cumulative impacts" and "low cumulative impacts." Finally, the "The Human Factor" axis had logics of "Exploitative" and "Stewardship."

\section{Scenario Logics}

Grouping the various axis logics together yielded eight possible scenario logics, though not all of the paired scenarios logics were plausible. For example, a scenario in which there are high cumulative impacts from land use, but human values reflecting a stewardship ethic seems contradictory. For this reason, participants deemed such contradictory combinations of scenario logics unlikely and so discarded them, leaving four viable scenarios.

\section{Scenarios}

The scenario team developed four alternate visions of the future southwest Yukon SES. Full scenario narratives are presented in Appendix 1. Scenario 1 (Doom and Gloom) features status quo management actions, resulting in low native ungulate populations and moderate new ungulate populations. Scenario 2 (Slow Boil) features high unintended consequences from managers being slow to react, resulting in low native ungulate populations and low new 
ungulate populations. Scenario 3 (A Confused State) features high unintended consequences from poorly planned management actions, resulting in low native ungulate populations but high new ungulate populations. Scenario 4 (Win-win) features carefully planned management actions, resulting in low-moderate native ungulate populations and moderate new ungulate populations.

\section{Understanding participants' perspectives}

Surveys revealed that scenario planning helped participants to think about how drivers interact, what uncertainty exists, and how to craft contextually appropriate management goals. All participants who completed survey $2(n=6)$ believed that they learned something from the scenario planning process that will be valuable to them as a manager, will be able to use outcomes from this process, and could see themselves using scenario planning in the future. These survey respondents agreed that scenario planning is a method that could help people with different perspectives collaborate and discuss issues. Survey 1 ( $\mathrm{n}$ $=8$ ) respondents agreed that the scenario planning process helped them understand other stakeholders' points of view.

\section{DISCUSSION: LESSONS LEARNED ABOUT SCENARIO PLANNING}

Participants described scenario planning as a method that enabled broad thinking and made sharing perspectives easier. They also suggested ways to improve the process and clarified the useful scope for scenario planning endeavors. We learned a number of practical lessons during this project, and we present these with the intent of informing future scenario planning efforts elsewhere. A concise summary of these lessons, especially for practitioners and managers, is presented in Box 1.

Box 1: Summarized Lessons for Scenario Planning Practitioners Content Lessons:

1. Management goals are specific to the context of each scenario, so searching for "no regrets" strategies may not be productive.

2. Scenario planning can help resource managers identify needs that have been overlooked but may become important in the future.

3. Scenarios can likely be used to develop management goals for other resources within the same system.

4. Scenario planning provides a way to apply traditional ecological knowledge and local knowledge in a planning process in a respectful manner.

5. Scenario planning can help people with different perspectives to collaborate by fostering an understanding of others' points of view.

Process Lessons:

1. Carefully define important terms, such as "uncertainty" and "system."

2. Describe each step of the scenario planning process, and how each step contributes toward the development of the scenarios, to help participants see how all the steps fit together and remain motivated.
3. Categorize drivers by scale prior to ranking.

4. Ensure continuity of workshop participants.

5. Minimize the length of time between sequential workshops: we recommend no greater than one month.

\section{Scenarios encouraged broad thinking}

Participants described how the holistic, ecosystem approach that considered species, human needs and values, and development helped them to visualize the effects of nonecological components of the SES on wildlife. When the thinking was centered on how interactions between drivers form causal relationships, participants were able to visualize potential threats that had not been previously discussed in southwest Yukon wildlife management circles. For example, scenario 2 revealed a value shift due to loss of wildlife. People showed less respect for the land because they had less opportunity to access and connect with it through hunting. Of survey 2 respondents, $83 \%$ agreed that scenario planning helped them understand future uncertainty. One participant said it "reinforced how events may dramatically alter management goals." Perhaps the most significant awareness that rose through the scenario planning process was potential unintended consequences of using management to "close the door" on one or more of the new species. Limiting the population growth of mule deer, for example, could induce cultural food insecurity in a future where other ungulate populations suffer. Systems thinking changes the goal from seeking knowledge of parts of the system to improving understanding of the dynamics of the whole system (Folke et al. 2005). Participants valued how the scenario planning process encouraged and required broad thinking, describing it as "different," "integrative," and "longterm." All participants agreed that the long-term nature of thinking in scenario planning is valuable and something generally missing from conventional wildlife management planning.

The collaborative aspects of the process enhanced people's ability to think broadly. Participants viewed collaborative discussion as helpful while identifying drivers of change, thinking about driver interaction, and during visualization of future scenarios. One participant said, "Brainstorming during planning allowed us to think about interactions." By discussing these elements in groups after periods of independent thinking, scenario team members were able to draw from each other's perspectives and experience. This sequenced discussion served to expand creativity while constraining implausible notions of the future. As one participant put it, "we got to sort it out together and come to a common understanding." This reaffirms suggestions that scenario planning helps generate a shared vision of the future or a shared mental model (Peterson et al. 2003a, Chermack 2004, Palomo et al. 2011).

Having diverse and extensive experience related to the decision focus further helped the scenario team think broadly. Specifically, extensive experience and a wide range of participant ages apparently helped the group identify a wide range of drivers of change (Table 2). One participant said being a renewable resource manager and dealing with individual drivers of change on a daily 
basis helped identify drivers. Another mentioned that working with communities and environmental assessments helped identify drivers. Such comments show how participatory scenario planning can help local stakeholders collectively think holistically about an SES. The points of view and experience of others helped participants "to visualize decades of cumulative effects of population growth and resource projects." This shows that participatory scenario planning can help stakeholders understand how drivers might interact to form causal relationships.

Giving voice to diverse perspectives is a goal of scenario planning (Peterson et al. 2003a). These might include economic, social, or cultural perspectives. Having more values or perspectives present could make consensus harder to reach at various points of the scenario planning process. Conversely, having a wide variety of values and perspectives can help to identify more possibilities of how the system might change in the future (Kok et al. 2007, Reed et al. 2013). In this study, having both First Nation and nonaboriginal cultural perspectives influenced the conversation about how to group drivers of change into axes of uncertainty. For example, one First Nation participant argued for the inclusion of several socially oriented drivers in what was a predominantly ecologically oriented axis of change. The participant explained this was necessary because humans are part of nature and some social drivers, such as "hunter patterns," are intimately tied to natural drivers, such as "moose." That one conversation helped other participants think holistically about the SES, enabling them to learn from each other and broaden their perspectives; a finding similar to Priess and Hauck (2014).

Overcoming cross-cultural misunderstanding is an enduring challenge for natural resource comanagement in the Yukon Territory (Nadasdy 2003, Natcher et al. 2005, Natcher and Davis 2007, Clark and Slocombe 2009). A scenario planning approach appears to be able to help First Nation and nonaboriginal resource managers generate shared understanding by improving both parties' understanding of each other's perspectives. In this study, all survey respondents agreed that scenario planning is a method that could help people with different perspectives collaborate and discuss issues. Similarly, $88 \%$ of survey respondents agreed that the scenario planning process helped to understand points of view of other stakeholders. These two findings indicate that scenario planning holds promise for clarifying and securing common ground between stakeholders with differing perspectives and values. For one participant, this was a "strength of the approach."

\section{Context matters when setting goals}

Some authors argue that scenario planning has an outcome of identifying "robust" strategies that can be applied across a range of future conditions (Ralston and Wilson 2006, Carvalho et al. 2011, Caves et al. 2013). Robust, or "no regrets" strategies were identified in past Yukon forest management workshops looking at different climate futures in the region. They were considered robust strategies because they could work under multiple possible climate futures (Ogden and Innes 2009). We found that in a wildlife management context participants were reluctant to sort wildlife management goals in this manner. Participants were very clear that they preferred to keep goals fixed in the contexts of individual scenarios; the reason being that management needs would be different in those different futures.
To further illustrate this point, five of the seven identified goal clusters (Beach 2014) could be applied across multiple scenarios. However, different management recommendations were made to achieve the goals under the varying contexts of the scenarios. For example, it is a goal to keep new species at socially tolerable, harvestable levels in all four scenarios. However, the individual steps to maintain wood bison populations would be different in scenario 3, where disease is prevalent in the population, than in scenario 1 where the population is disease-free. The social tolerance for wood bison could be much lower in a scenario where the herd was diseased. As such, corresponding management needs would likely be different. Consequently, it appears important not to lose the aspects of a clustered goal that root it to the conditions of a specific scenario.

It is worth noting that in the southwest Yukon species-specific technical teams write the species management plans and a renewable resource council is mandated as the key institution of public government involved in environmental management within a corresponding First Nation traditional territory. Our goals were set at the regional level by participants representing the technical teams and renewable resource councils governing the wood bison and elk ranges.

Another point to highlight is the importance of context. The narrative format of the scenarios helps create a hypothetical situation that may remove participants' personal investment compared with day-to-day situations. One participant said, "being part of the story makes it less provocative," while another added that "I don't feel like I'm being personally attacked." Discussing issues through story could ease the tension surrounding familiar issues. For example, when participants discussed a potential coal power plant there was less weight attached because it was a hypothetical (though plausible) project. There were few or no past conversations, impact assessments, or heated debates surrounding it. This may contribute to why all participants felt that scenario planning could be a helpful method for stakeholders with diverse perspectives and values to discuss complex and/or contentious issues, a finding shared by Caves et al. (2013).

\section{Developed scenarios may have wider applicability in context}

Despite the need to link goals explicitly with specific scenario contexts, study participants observed that within those contexts, scenarios could be relevant for managing resources beyond wildlife. Participants found scenario planning helpful to set priorities for wildlife management, raise awareness of potential threats, identify future monitoring and resource needs, examine long-term repercussions of management actions, stimulate the sharing of perspectives, and build capacity. Participants also felt that scenario planning could be particularly useful in generating a wildlife management plan, a species recovery document, a landuse plan, or when conducting risk or resilience assessments. It was mentioned, in retrospect, that the Yukon Wood Bison Management Plan (2012) could have benefitted from a scenario planning process.

Participants also saw potential value in applying the scenarios when considering management for other species and/or resources within the same system. This is an important finding. Scenario narratives describe several versions of the future system with a 
focus on a particular element. However, groups interested in focusing the scenarios on a different element, say wolves or coniferous forests rather than new ungulates, could use the "bones" of the scenarios because they were built considering the system holistically. The causal relationships considered during the original scenario development process will still apply. They would simply need to be refocused to address how the resulting events could affect the newly emphasized element.

\section{Improving the process}

\section{Time}

Latency posed a problem. Significant time between workshops led participants to forget the meaning and context behind drivers of change. Participants also had difficulty remembering fine details of the scenarios by the time they were discussed. This could be avoided by keeping to the recommended timetable of 3-4 months (Ralston and Wilson 2006), with roughly 1 month between each workshop. This puts significant demands on the scenario narrative writer, but reinforces the scenario team members' memory of workshop events and context.

As studies have noted elsewhere, it is important to ensure enough time is given for all scenario planning steps to unfold (Kok et al. 2007, Walz et al. 2007). In this process, participants felt that there needed to be more time to develop and discuss management goals. Furthermore, because the third workshop was only a single day there was no time left to develop indicators. As a result, this planning process was missing an aspect fundamental to operationalizing the resulting management goals.

\section{Continuity of participants}

Continuity of workshop participants was also a problem. Because this was a voluntary study, participants were not obligated to attend. Coordinating a time when all participants were available was challenging, and several participants did not attend all three workshops. Some apparently lost interest after the first workshop, whereas other new participants became interested as they heard about the project, so came to subsequent workshops. Participants who attended only the final workshop were missing context from the previous workshops and at times seemed to have trouble adjusting to the group's thinking.

Ideally, participants will commit to all workshops if possible, ensuring continuity of the participants and the perspectives represented. More robust management goals may be possible from a scenario team that understands the context from the entire scenario development process. Workshops done within an institution with employees whose attendance was part of their regular work likely would not experience the same problem.

\section{Clarity of process}

Throughout the scenario planning process, there were points where participants felt unsure of how the sum of the parts would add up to the whole, or what the whole even was. At those times clarification was required. This indicates the importance of explaining the full extent of the process to participants at the beginning, and being prepared to remind participants of it. It was evident that knowing how each step of the process worked toward the ultimate goal helped participants perform each step and stay engaged.

For example, the process of ranking drivers caused confusion. Multiple participants perceived issues with scale, feeling that some drivers could be nested within other drivers. Mining exploration and production, for example, both fit within the larger driver of natural resource demand. By ranking one as higher impact than the others, would they necessarily reduce the importance of the others that are related? Grouping similar drivers prior to ranking the drivers could reduce confusion of scale when ranking. Similarly, when asked to identify drivers of change, some participants wanted clarification about what the drivers were to be used for, or how general or specific the drivers should be. Seeing examples from other scenario planning workshops was helpful in those instances.

\section{Definitions}

A related problem was that at times participants found themselves working with a different set of definitions. People's interpretations of words differed, likely because of varying cultural or professional understandings. A particular issue was how to define the word "uncertainty" with reference to the drivers of change. Some participants took it to mean uncertainty of occurrence, while others thought it to mean uncertainty of impact. This may well have introduced variation in how participants ranked drivers.

Because this scenario process was rooted in SES theory, the researchers constantly referred to "the entire system." What exactly was entailed in "the entire system" gave participants trouble. For some, thinking in this way was problematic. These participants had trouble combining aspects of the human economy and environmental interactions into the same thought. Others already had an operationalized understanding of what it means for an environment to also contain human social and economic interactions. This difference in understanding necessitated extended discussions about how to group drivers and discuss how drivers might interact into the future. This also reinforced the benefit from scenario planning of challenging people to understand each other's perspectives and values.

\section{Facilitating adaptive learning}

The following insights were gained by the researchers outside of the scenario workshops, but from observations made during the workshops. Our results are consistent with the case many have made that scenario planning provides resource managers with a method to operationalize theories about managing dynamic social-ecological systems.

A process that generates knowledge and experience of ecosystem dynamics improves the social capacity of responding to environmental change (Folke et al. 2005). This becomes true when the generated learning is expressed in management practice (Folke et al. 2005). Keeping the above two points in mind, this study suggests that scenario planning is a process that fosters adaptive learning. In resource management, adaptive learning "provides the means for coping with uncertainty and change in a socialecological environment" (Kofinas 2009:96). Kofinas (2009) claims that adaptive learning occurs when one or more groups does the following:

1. Observe social-ecological conditions,

2. Draw on those observations to improve understanding of the system's behavior,

3. Evaluate the implications of emergent conditions and options for action, and

4. Respond in ways that support the resilience of the SES. 
Engaged resource managers should be continually undertaking the first of these activities. Taking resource managers through the scenario planning process helped them to engage in the remaining three. Specifically, identifying drivers of change and axes of uncertainty parallels activity 2 . Thinking about how drivers and axes interact to form future scenarios as well as examining threats and opportunities parallels the first part of activity 3 (evaluate emergent conditions). Discussing possible management options parallels the second part of activity 3 (evaluate options for action). Last, developing management goals, monitoring needs, and identifying signposts that indicate the need for management action lays essential groundwork for activity 4.

Scenario planning can likely further enhance the adaptiveness of a management regime by providing a forum for single-loop, double-loop, and triple-loop learning (Argyris and Schön 1974, 1978, Keen et al. 2005). Each of these learning mechanisms involves cyclical, experiential learning in which practitioners reflect on the results of past actions. Single-loop learning permits the organization to continue its present policies or achieve its present objectives (Argyris and Schön 1974). Importantly, individuals do not question the fundamental goals (double-loop) and design of the organization (triple-loop; Argyris and Schön 1974). In a resource management context, single-loop learning refers to adjusting actions to meet previously identified management goals (Kofinas 2009). For example, participants in this study engaged in single-loop learning by recommending opening bison hunting to subsistence harvesting. Managers looked at population levels being high and suggested increasing the harvest by adding wood bison to the list of subsistence species for First Nations. The goal of harvesting bison remained intact.

Double-loop learning involves the modification of an organization's policies or objectives (Argyris and Schön 1978). Within natural resource management, practitioners reflect on consequences of past management actions before taking further actions (Kofinas 2009). The feature that distinguishes single-loop learning from double-loop learning is that double-loop learning calls into question basic assumptions and goals. Study participants engaged with double-loop learning when they reflected under each scenario whether or not to prioritize management of culturally sensitive species. They looked at shifting management goals to ensure new species remain at socially acceptable levels. Scenario planning helped participants think about whether existing management goals would be appropriate under different conditions.

Triple-loop, or transformative, learning, challenges the institutional assumptions upon which single-loop and doubleloop learning are based (Keen et al. 2005). It involves a reevaluation of models and approaches as in double-loop learning, but adds a consideration of whether the alteration of norms or goals might require a paradigm shift in governance (Keen et al. 2005, Folke et al. 2009). It is the difference between changing a goal, such as prioritizing management of culturally sensitive species, and changing the process by which a goal is developed. Participants in this study engaged with triple-loop learning by questioning the efficacy of the current processes available to them for planning wildlife management goals. Through reflecting, participants saw value in a holistic, long-term approach to developing management goals. This spurred them to recommend that longer term planning approaches, such as scenario planning, be conducted prior to developing management goals. Implementing a parallel planning process would shift the current planning paradigm for wildlife management away from single-species foci and short-term time horizons toward longer term, holistic thinking.

Developing management goals through the scenario planning process simultaneously takes managers through iterations of an adaptive learning cycle. Within a scenario planning process managers can devise plans to adjust actions, or develop entirely new approaches to meet goals based on new assumptions. With the right decision focus, a scenario team can even investigate a change in governance paradigms.

\section{Enhancing institutional linkages}

Successful adaptive comanagement depends on social networks between individuals, groups, and organizations that allow for multidirectional information flows (Gadgil et al. 2003, Olsson et al. 2004, 2006, Folke et al. 2005, Armitage et al. 2007, Kofinas 2009). The success of such networks relies on the collaboration of a diverse set of stakeholders operating at a range of scales. Sharing of management power and responsibility may involve multiple institutional linkages between organizations (Folke et al. 2005).

Our findings suggest that scenario planning provides mechanisms to build, or to strengthen, institutional linkages. Of all survey respondents, $88 \%$ agreed that scenario planning helped them understand points of view of other stakeholders. All respondents to the second survey agreed that scenario planning could help people with different perspectives collaborate and discuss issues. By helping organizations to build trust and discuss shared mental models of plausible futures, scenario planning can further contribute to the success of adaptive comanagement (Peterson 2007). Our scenario planning process evidently facilitated multidirectional informational flows between all represented organizations, a finding shared by Stringer et al. (2006). However, we did not examine the potential impact of improving informational flows, which, to be conclusive, would have required longer term structured follow-up.

Scenario planning processes can empower local participants by communicating social-ecological change with high salience (Sheppard et al. 2011, Reed et al. 2013), encouraging the actual use of outputs that have been cogenerated (Kok et al. 2007, Walz et al. 2007), and encouraging flexible participation (Stringer et al. 2006). Our participants found it provided a forum where everyone in attendance could equally provide input and feedback. Such interaction can potentially empower groups that may believe their perspectives are underrepresented under current governance models.

Scenario planning processes can accept input from a wide range of knowledge systems, thereby enhancing linkages between organizations possessing different ways of knowing. Input from multiple, especially local knowledge, systems is an important way to deepen researcher understanding of system dynamics and add validity to localized scenarios (Walz et al. 2007). Modern science is a well-organized system for expanding the world's knowledge. However, it lacks the wealth of detailed, context-specific observations of the dynamics of complex ecological systems that 
can be found in some local knowledge (Gadgil et al. 2003). In fact, many local resource users of the world possess, as parts of their knowledge systems, site-specific knowledge of how to respond to disturbance and build adaptive capacity to changes (Berkes and Folke 2002, Chapin et al. 2009). Local knowledge systems offer important insights, and is why environmental governance needs collaboration among diverse stakeholders (Plummer and Armitage 2010). Qualitative, participatory scenario planning workshops provide a forum to share these insights.

\section{CONCLUSIONS}

This application-oriented study has locally specific yet broadly relevant findings. We learned that scenario planning is a method that can successfully develop wildlife management goals. It helped local and regional resource managers better understand local SES dynamics and uncertainty. It prompted them to consider potential impacts of various wildlife management goals on SES dynamics, and vice versa. To improve the process, we offer some key findings from our experience. Scenario practitioners should insist on commitment from participants, because continuity improves understanding of process context. Time between workshops should be minimized and workshops should be given sufficient time to accomplish all steps of the scenario planning process. Following these recommendations should improve the robustness and usefulness of scenario outputs.

We also demonstrate that participatory scenario planning can be used as a foundational process toward SES-based management goals. Undertaking this thought process can help wildlife managers articulate goals with a deeper understanding of a goal's implications to the rest of the SES. Identifying system drivers and future-oriented goals can lead to proactive management, rather than, as one participant put it, just reacting to a squeaky wheel that needs grease. Planning more holistically and improving interorganizational information flows and relationships were two observed outcomes seen by participants as likely to lead to more adaptive, effective wildlife management. For these reasons, participants felt that instilling a culture where these types of processes preceded conventional planning would be extremely useful in the Yukon. Such institutional challenges are hardly limited to wildlife management either, as participants noted. Our findings thus have broad relevance to professional practice in natural resource and environmental management, especially as the shortcomings of top-down expert-driven "scientific management" in the face of rapid change spur experimentation with new forms of adaptive governance for social-ecological systems (Brunner et al. 2005, Folke et al. 2005).

Responses to this article can be read online at: http://www.ecologyandsociety.org/issues/responses. $\mathrm{php} / 7379$

\section{Acknowledgments:}

A series of people and institutions helped to make this article possible. Special thanks to the workshop participants for taking four grueling days from their busy lives to talk to us, and think hard. Specifically, we thank the Alsek Renewable Resource Council,
Carmacks Renewable Resource Council, Champagne \& Aishihik First Nations, Environment Canada, Parks Canada, Ta'an Kwäch'än Council, Yukon Territorial Government, Yukon Fish and Wildlife Management Board, and Yukon Fish and Game Association for sending members to one or more workshops. We thank Tanya Handley for producing the scenario graphics. This study was financially supported by the Social Science and Humanities Research Council of Canada and the University of Saskatchewan.

\section{LITERATURE CITED}

Alcamo, J. 2008. The SAS approach: combining qualitative and quantitative knowledge in environmental scenarios. Pages 123-150 in J. Alcamo and T. Henrichs, editors. Environmental futures: the practice of environmental scenario analysis. Elsevier, Amsterdam, The Netherlands. http://dx.doi.org/10.1016/S1574-101X (08)00406-7

Alcamo, J., and T. Henrichs, editors. 2008. Towards guidelines for environmental scenario analysis. Pages 13-35 in J. Alcamo and T. Henrichs, editors. Environmental futures: the practice of environmental scenario analysis. Elsevier, Amsterdam, The Netherlands.

Alcamo, J., D. Van Vuuren, C. Ringler, J. Alder, E. Bennett, D. Lodge, T. Masui, T. Morita, M. Rosegrant, O. Sala, et al. 2005. Methodology for developing the MA scenarios. Chapter 6 in S. R. Carpenter, editor. Ecosystems and human well-being: scenarios, Volume 2. Island Press, Washington, D.C., USA.

Argyris, C., and D. Schön. 1974. Theory in practice: increasing professional effectiveness. Jossey-Bass, San Francisco, California, USA.

Argyris, C., and D. A. Schön. 1978. Organizational learning: a theory of action perspective. Jossey-Bass, San Francisco, California, USA. http://dx.doi.org/10.2307/40183951

Armitage, D., F. Berkes, and N. Doubleday. editors. 2007. Adaptive co-management: collaboration, learning, and multi-level governance. University of British Columbia Press, Vancouver, British Columbia, Canada.

Beach, D. 2014. Lessons from scenario planning for wildlife management in the southwest Yukon. Thesis. University of Saskatchewan, Saskatoon, Canada. [online] URL: http:// ecommons.usask.ca/handle/10388/ETD-2014-01-1405

Beaumont, L. J., L. Hughes, and A. J. Pitman. 2008. Why is the choice of future climate scenarios for species distribution modeling important? Ecology Letters 11:1135-1146.

Berkes, F., J. Colding, and C. Folke, editors. 2003. Navigating social-ecological systems: building resilience for complexity and change. Cambridge University Press, Cambridge, UK. http://dx. doi.org/10.1017/CBO9780511541957

Berkes, F., and C. Folke. 2002. Back to the future: ecosystem dynamics and local knowledge. Pages 121-146 in L. H. Gunderson and C. S. Holling, editors. Panarchy: understanding transformation in systems of human and nature. Island Press, Washington, D.C., USA. 
Berkes, F., C. Folke, and J. Colding, editors. 1998. Linking social and ecological systems: management practices and social mechanisms for building resilience. Cambridge University Press, Cambridge, UK.

Bohensky, E. L., B. Reyers, and A. S. van Jaarsveld. 2006. Future ecosystem services in a southern African river basin: a scenario planning approach to uncertainty. Conservation Biology 20 (4):1051-1061. http://dx.doi.org/10.1111/j.1523-1739.2006.00475. $\underline{\mathrm{x}}$

Brunner, R. D., T. A. Steelman, L. Coe-Juell, C. M. Cromley, C. M. Edwards, and D. W. Tucker. 2005. Adaptive governance: integrating science, policy, and decision making. Columbia University Press, New York, New York, USA.

Carpenter, S. R. 2002. Ecological futures: building an ecology of the long now. Ecology 83(8):2069-2083. http://dx.doi. org/10.2307/3072038

Carvalho, S. B., J. C. Brito, E. G. Crespo, M. E. Watts, and H. P. Possingham. 2011. Conservation planning under climate change: toward accounting for uncertainty in predicted species distributions to increase confidence in conservation investments in space and time. Biological Conservation 144:2020-2030. http:// dx.doi.org/10.1016/j.biocon.2011.04.024

Caves, J. K., G. S. Bodner, K. Simms, L. A. Fisher, and T. Robertson. 2013. Integrating collaboration, adaptive management, and scenario-planning: experiences at Las Cienegas National Conservation Area. Ecology and Society 18(3): 43. http://dx.doi. org/10.5751/ES-05749-180343

Chapin III, F. S., A. L. Lovecraft, E. S. Zavaleta, J. Nelson, M. D. Robards, G. P. Kofinas, S. F. Trainor, G. D. Peterson, H. P. Huntington, and R. L. Naylor. 2006. Policy strategies to address sustainability of Alaskan boreal forests in response to a directionally changing climate. Proceedings of the National Academy of Sciences 103(45):16637-16643. http://dx.doi. org/10.1073/pnas.0606955103

Chapin III, F. S., G. P. Kofinas, C. Folke, S. R. Carpenter, P. Olsson, N. Abel, R. Biggs, R. L. Naylor, E. Pinkerton, D. M. Stafford Smith, W. Steffen, B. Walker, and O. Young. 2009. Resilience-based stewardship: strategies for navigating sustainable pathways in a changing world. Pages 319-337 in C. Folke, G. P. Kofinas, and F. S. Chapin, editors. 2009. Principles of ecosystem stewardship. Springer, New York, New York, USA. http://dx.doi. org/10.1007/978-0-387-73033-2 15

Chermack, T. J. 2004. Improving decision-making with scenario planning. Futures 36:295-309. http://dx.doi.org/10.1016/S0016-3287 (03)00156-3

Chermack, T. J., S. A. Lynham, and W. E. A. Ruona. 2001. A review of scenario planning literature. Futures Research Quarterly $7(2): 7-32$.

Clark, D. A., and D. S. Slocombe. 2009. Respect for grizzly bears: an aboriginal approach for co-existence and resilience. Ecology and Society 14(1): 42. [online] URL: http://www.ecologyandsociety. org/vol14/iss1/art42/

Cruikshank, J. 2005. Do glaciers listen? Local knowledge, colonial encounters, and social imagination. University of British Columbia Press, Vancouver, British Columbia, Canada.
Duinker, P. N., and L. A. Greig. 2007. Scenario analysis in environmental impact assessment: improving explorations of the future. Environmental Impact Assessment Review 27(3):206-219. http://dx.doi.org/10.1016/j.eiar.2006.11.001

Folke, C. 2006. Resilience: the emergence of a perspective for social-ecological systems analyses. Global Environmental Change 16:253-267. http://dx.doi.org/10.1016/j.gloenvcha.2006.04.002

Folke, C., F. S. Chapin III, and P. Olsson. 2009. Transformations in ecosystem stewardship. Pages 103-125 in F. S. Chapin III, G. P. Kofinas, and C. Folke, editors. 2009. Principles of ecosystem stewardship. Springer, New York, New York, USA.

Folke, C., T. Hahn, P. Olsson, and J. Norberg. 2005. Adaptive governance of social-ecological systems. Annual Review of Environment and Resources 30:441-473. http://dx.doi.org/10.1146/ annurev.energy.30.050504.144511

Fuller, T., D. P. Morton, and S. Sarkar. 2008. Incorporating uncertainty about species' potential distributions under climate change into the selection of conservation areas with a case study from the Arctic Coastal Plain of Alaska. Biological Conservation 141:1547-1559. http://dx.doi.org/10.1016/j.biocon.2008.03.021

Gadgil, M., P. Olsson, F. Berkes, and C. Folke. 2003. Exploring the role of local ecological knowledge in ecosystem management: three case studies. Pages 189-209 in F. Berkes, J. Colding, and C. Folke, editors. Navigating social-ecological systems: building resilience for complexity and change. Cambridge University Press, Cambridge, UK. http://dx.doi.org/10.1017/CBO9780511541957.013

Gibon, A., D. Sheeren, C. Monteil, S. Ladet, and G. Balent. 2010. Modelling and simulating change in reforesting mountain landscapes using a social-ecological framework. Landscape Ecology 25:267-285. http://dx.doi.org/10.1007/s10980-009-9438-5

González, J. A., C. Montes, J. Rodríguez, and W. Tapia. 2008. Rethinking the Galapagos Islands as a complex social-ecological system: implications for conservation and management. Ecology and Society 13(2): 13. [online] URL: http://www.ecologyandsociety. org/vol13/iss2/art13/

Huntington, H. P., P. K. Brown-Schwalenberg, K. J. Frost, M. E. Fernandez-Gimenez, D. W. Norton, and D. H. Rosenberg. 2002. Observations on the workshop as a means of improving communication between holders of traditional and scientific knowledge. Environmental Management 30(6):778-792. http://dx. doi.org/10.1007/s00267-002-2749-9

Intergovernmental Panel on Climate Change (IPCC). 2000. IPCC Special report: emissions scenarios. IPCC, Geneva, Switzerland.

Jensen, R. A., J. Madsen, M. O’Connell, M. S. Wisz, H. Tømmervik, and F. Mehlum. 2008. Prediction of the distribution of Arctic-nesting pink-footed geese under a warmer climate scenario. Global Change Biology 14:1-10.

Kay, J. J. 2008. An introduction to systems thinking. Pages 3-14 in D. Waltner-Toews, J. J. Kay, and N.-M. E. Lister, editors. 2008. The ecosystem approach: complexity, uncertainty and managing for sustainability. Columbia University Press, New York, New York, USA.

Keen, M., V. Brown, and R. Dybal. 2005. Social learning in environmental management. Earthscan, London, UK. 
Kofinas, G. P. 2009. Adaptive co-management in social-ecological governance. Pages 77-102 in F. S. Chapin, III, G. P. Kofinas, and C. Folke, editors. 2009. Principles of ecosystem stewardship: resilience-based natural resource management in a changing world. Springer, New York, New York, USA. http://dx.doi. org/10.1007/978-0-387-73033-2_4

Kok, K., R. Biggs, and M. Zurek. 2007. Methods for developing multiscale participatory scenarios: insights from southern Africa and Europe. Ecology and Society 13(1): 8. [online] URL: http:// www.ecologyandsociety.org/vol12/iss1/art8/

Kok, K., M. Patel, and D. S. Rothman. 2004. Final report of European and Mediterranean scenarios: upscaling the results from the target area scenarios. MedAction Deliverable 4. International Centre for Integrated assessment and Sustainable development (ISIS) working paper I04-E002. Maastricht University, Maastricht, The Netherlands.

Maiorano, L., A. Falcucci, N. E. Zimmermann, A. Psomas, J. Pottier, D. Baisero, C. Rondinini, A. Guisan, and L. Boitani. 2011. The future of terrestrial mammals in the Mediterranean basin under climate change. Philosophical Transactions of the Royal Society B 366:2681-2692. http://dx.doi.org/10.1098/rstb.2011.0121

Malinga, R., L. J. Gordon, R. Lindborg, and G. Jewitt. 2013. Using participatory scenario planning to identify ecosystem services in changing landscapes. Ecology and Society 18(4): 10. http://dx.doi.org/10.5751/ES-05494-180410

Millennium Ecosystem Assessment (MEA). 2005. Ecosystems and human well-being: scenarios, Volume 2. Island press, Washington, D.C., USA.

Nadasdy, P. 2003. Reevaluating the co-management success story. Arctic 56:367-380. http://dx.doi.org/10.14430/arctic634

Natcher, D. C., and S. Davis. 2007. Rethinking devolution: challenges for Aboriginal resource management in the Yukon Territory. Society \& Natural Resources 20(3):271-279. http://dx. doi.org/10.1080/08941920601117405

Natcher, D. C., S. Davis, and C. G. Hickey. 2005. Co-management: managing relationships, not resources. Human Organization 64 (3):240-250.

Ogden, A. E., and J. L. Innes. 2009. Application of structured decision making to an assessment of climate change vulnerabilities and adaptation options for sustainable forest management. Ecology and Society 14(1): 11. [online] URL: http:// www.ecologyandsociety.org/vol14/iss1/art11/

Olsson, P., C. Folke, and F. Berkes. 2004. Adaptive comanagement for building resilience in social-ecological systems. Environmental Management 34(1):75-90. http://dx.doi.org/10.1007/s00267-003-0101-7

Olsson, P., L. H. Gunderson, S. R. Carpenter, P. Ryan, L. Lebel, C. Folke, and C. S. Holling. 2006. Shooting the rapids: navigating transitions to adaptive governance of social-ecological systems. Ecology and Society 11(1): 18. [online] URL: http://www. ecologyandsociety.org/vol11/iss1/art18/

Palacios-Agundez, I., I. Casado-Arzuaga, I. Madariaga, and M. Onaindia. 2013. The relevance of local participatory scenario planning for ecosystem management policies in the Basque
Country, northern Spain. Ecology and Society 18(3): 7. http://dx. doi.org/10.5751/ES-05619-180307

Palomo, I., B. Martín-López, C. López-Santiago, and C. Montes. 2011. Participatory scenario planning for protected areas management under the ecosystem services framework: the Doñana social-ecological system in southwestern Spain. Ecology and Society 16(1): 23. [online] URL: http://www.ecologyandsociety. org/vol16/iss1/art23/

Parmesan, C., and G. Yohe. 2003. A globally coherent fingerprint of climate change impacts across natural systems. Nature 421 (6918):37-42. http://dx.doi.org/10.1038/nature01286

Peterson, G. 2007. Using scenario planning to enable an adaptive co-management process in the Northern Highlands Lake District of Wisconsin. Pages 286-307 in D. Armitage, F. Berkes, and N. Doubleday, editors. Adaptive co-management: collaboration, learning, and multi-level governance. University of British Columbia Press, Vancouver, British Columbia, Canada.

Peterson, G. D., T. D. Beard, Jr, B. E. Beisner, E. M. Bennett, S. R. Carpenter, G. S. Cumming, C. L. Dent, and T. D. Havlicek. 2003b. Assessing future ecosystem services: a case study of the Northern Highlands Lake District, Wisconsin. Conservation Ecology 7(3): 1. [online] URL: http://www.ecologyandsociety.org/ vol7/iss $3 / \operatorname{art1/}$

Peterson, G. D., G. S. Cumming, and S. R. Carpenter. $2003 a$. Scenario planning: a tool for conservation in an uncertain world. Conservation Biology 17:358-366. http://dx.doi.org/10.1046/ j.1523-1739.2003.01491.X

Plummer, R., and D. Armitage. 2010. Integrating perspectives on adaptive capacity and environmental governance. Pages 1-19 in D. Armitage and R. Plummer, editors. Adaptive capacity and environmental governance. Springer, Heidelberg, Germany. http:// dx.doi.org/10.1007/978-3-642-12194-4 1

Priess, J. A., and J. Hauck. 2014. Integrative scenario development. Ecology and Society 19(1): 12. http://dx.doi. org/10.5751/ES-06168-190112

Ralston, B., and I. Wilson. 2006. The scenario planning handbook: a practitioner's guide to developing and using scenarios to direct strategy in today's uncertain times. Texere, New York, New York, USA.

Reed, M. S., J. Kenter, A. Bonn, K. Broad, T. P. Burt, I. R. Fazey, E. D. G. Fraser, K. Hubacek, D. Nainggolan, C. H. Quinn, L. C. Stringer, and F. Ravera. 2013. Participatory scenario development for environmental management: a methodological framework illustrated with experience from the UK uplands. Journal of Environmental Management 128:345-362. http://dx.doi.org/10.1016/ j.jenvman.2013.05.016

Rose, N.-A., and P. J. Burton. 2011. Persistent climate corridors: the identification of climate refugia in British Columbia's central interior for the selection of candidate areas for conservation. $B C$ Journal of Ecosystems and Management 12(1):101-117.

Schoemaker, P. J. H. 1995. Scenario planning: a tool for strategic thinking. Sloan Management Review 36(2):25-40.

Sheppard, S. R. J., A. Shaw, D. Flanders, S. Burch, A. Wiek, J. Carmichael, J. Robinson, and S. Cohen. 2011. Future visioning 
of local climate change: a framework for community engagement and planning with scenarios and visualisation. Futures 43 (4):400-412. http://dx.doi.org/10.1016/j.futures.2011.01.009

Slocombe, D. S. 2001. Climate and other sources of change in the St. Elias region. Pages 61-69 in G. Visconti, M. Beniston, E. D. Iannorelli, and D. Barba, editors. Global change and protected areas. Springer, New York, New York, USA. http://dx.doi. org/10.1007/0-306-48051-4 8

Smith, C. A. S., J. C. Meikle, and C. F. Roots, editors. 2004. Ecoregions of the Yukon Territory: biophysical properties of Yukon landscapes. PARC Technical Bulletin No. 04-01, Agriculture and Agri-Food Canada, Summerland, British Columbia.

Stringer, L. C., A. J. Dougill, E. Fraser, K. Hubacek, C. Prell, and M. S. Reed. 2006. Unpacking "participation" in the adaptive management of social-ecological systems: a critical review. Ecology and Society 11(2): 39. [online] URL: http://www. ecologyandsociety.org/vol11/iss2/art39/

Swart, R. J., P. Raskin, and J. Robinson. 2004. The problem of the future: sustainability science and scenario analysis. Global Environmental Change 14(2):137-146. http://dx.doi.org/10.1016/ j.gloenvcha.2003.10.002

United Nations Environment Programme (UNEP). 2007. Global environmental outlook 4: environment for development. Progress Press, Valleta, Malta.

Vervoort, J. M., K. Kok, R. van Lammeren, and T. Veldkamp. 2010. Stepping into futures: exploring the potential of interactive media for participatory scenarios on social-ecological systems. Futures 42:604-616. http://dx.doi.org/10.1016/j.futures.2010.04.031

Walker, B., S. Carpenter, J. Anderies, N. Abel, G. S. Cumming, M. Janssen, L. Lebel, J. Norberg, G. D. Peterson, and R. Pritchard. 2002. Resilience management in social-ecological systems: a working hypothesis for a participatory approach. Conservation Ecology 6(1): 14. [online] URL: http://www. ecologyandsociety.org/vol6/iss1/art14/

Walker, B., C. S. Holling, S. R. Carpenter, and A. Kinzig. 2004. Resilience, adaptability and transformability in social-ecological systems. Ecology and Society 9(2): 5. [online] URL: http://www. ecologyandsociety.org/vo19/iss2/art5/

Walz, A., C. Lardelli, H. Behrendt, A. Grót-Regamey, C. Lundström, S. Kytzia, and P. Bebi. 2007. Participatory scenario analysis for integrated regional modelling. Landscape and Urban Planning 81:114-131. http://dx.doi.org/10.1016/j.landurbplan.2006.11.001

Weeks, D., P. Malone, L. Welling. 2011. Climate change scenario planning: a tool for managing parks into uncertain futures. Park Science 28(1):26-40.

Wollenberg, E., D. Edmunds, and L. Buck. 2000. Anticipating change: scenarios as a tool for adaptive forest management. Center for International Forestry Research. SMT Grafi ka Desa Putera, Indonesia. 
Appendix 1. Scenario narratives.

Scenario Story Line - S1 - "Doom and Gloom"

High Cumulative Impacts, Unpredictable Change, Exploitative

\section{Yukon Herald $\quad$ - $\quad$ October 11, 2032}

\section{Yukoners Work/Play Hard as Landscape Changes Around Them}

"What happened to hunting to fill your freezer?" is a commonly uttered question lately. In Supergrocery's weekly sale pamphlet, chicken breast was listed at $\$ 3.38 / \mathrm{lb}$., the same price as in Toronto.

Because of cheap groceries, the surge of wage jobs, and changes to species composition and abundance out on the land, people hunt less frequently and mostly recreationally.

For those who continue to hunt, hunting has become a different ball game. During the past seven years, due to the "conservation concerns" provisions of the Umbrella Final Agreement, First Nation members have had hunting priority for caribou, sheep, and moose. This has meant that nonFirst Nation hunters have had to try their luck exclusively with elk, bison, or deer.

"Growing up we ate moose meat," says 32 year-old and avid hunter Simon Caliber while looking up from a freezer full of venison. "There hasn't even been a lottery for a caribou tag in several years. It's still meat but it's just not the same."

According to Whitehorse District Conservation Officer Jim Walker, even though elk and wood bison populations have grown, the decline in hunting is not surprising. "Hunting takes time. A lot more time than walking down a grocery aisle." He continues to say, "I think a lot of it has to do with what people grew up with and people moving here from southern provinces may not have grown up with hunting as a way to put food on the table."

Though even for First Nations it's not all roses. Felix Jackson says, "There aren't enough caribou and moose anymore to hunt those animals alone and we don't have subsistence rights to bison and elk. If you want tags you have to pay. To pay you need a job. If you have a job you can only hunt on time off so you need a truck and a snowmobile to hunt faster. Since you have the truck and snowmobile you need the job. It is a cycle. Once you start you are stuck. Those subsistence ways are old ways."

Because of reduced hunting pressure wildlife management and economic development on the landscape are the main things contesting growing numbers of elk, wood bison and deer.

"These species are taking over the ranges of caribou, moose and sheep. Simply put, they are better able to adapt to the current circumstances." By current circumstances, Kluane Region Wildlife Biologist Leanne Rogers refers mostly to the human exploitative pressures that have changed wildlife habitat, but the landscape has changed in ways beyond human control as well.

\footnotetext{
"The part that blows my mind is the variability. The weather can't make up its mind."
} 
As far as averages go, there is a trend towards warmer, wetter weather and increasing average temperature is the alleged culprit for much of the changes. "Subtle changes to temperature can cause a host of environmental responses. Everything is so closely linked," says Karen Chang of Environment Yukon.

The story of climate in the SW Yukon can hardly be told by averages. In 2014 the Intergovernmental Panel on Climate Change flagged the western Arctic rim of North America as the "miner's canary." The southwest Yukon in particular has shown the rest of the world that climate change means extreme, unpredictable events.

"The part that blows my mind is the variability," says Carmacks resident Keith Steady. "One year there is record setting snowfall and the next year there is a record low. There is rain one summer, then drought. The weather can't make up its mind."

The great swings in temperature from year to year have huge affects on snowpack, permafrost, and ice. Flooding has become the major concern across the southwest Yukon.

Homeowner Dan Lenza says, "Water levels on my land change yearto-year it seems," an observation that is not an exaggeration. New ponds and wetlands appear suddenly as permafrost thaws, snowpack melts earlier and the pace of glacial melt quickens.

"Our river basins in the Yukon are experiencing higher volumes of water than ever before and it's changing everything," says Kathy Streams from the Department of Water Resources.

$$
\text { Kluane Region Wildlife }
$$

Biologist Leanne Rogers says that wildlife is also having a hard time adjusting to the variability. "Just last February both the Aishihik Caribou Herd and the Aishihik Wood Bison Herd had animals fall through thin ice. There weren't enough cold days in a row for ice to thicken enough to support their weight."

Rogers claims that the estimated 25 caribou that fell into the Nisling River was a significant blow to the population, but the over 100 bison that fell into Kloo Lake was barely a dent in the population.

\section{"As the southwest Yukon warms the spruce bark beetle becomes more and more of a problem."}

Forester Jane Timber says that the severe weather and high levels of industrial activity in the southwest Yukon has made white spruce stands more susceptible to pests such as the spruce bark beetle.

According to Environment Yukon's Karen Chang the warmer climate has helped some new pest insects move further north into the Yukon, such as the mountain pine beetle. More importantly, though, the time required for beetles to reach adulthood is shorter and more beetles are surviving the winter.

A weakened host and strengthened pest has been the recipe for increased beetle outbreaks and large swaths of beetle-killed forest throughout the SW Yukon.

Kluane Region Wildlife Biologist Leanne Rogers says, "As the southwest Yukon warms the spruce bark beetle becomes more and more of a problem. Beetle-killed spruce forest is mostly dead habitat for several years until the wind breaks off enough of the light blocking branchlets of the spruce 
trees. Outbreaks have had tremendous impact on white spruce stands which provide good habitat for caribou and moose."

When a forest stand becomes the site of a beetle outbreak it is privately logged and sold as woodstove fuel. But this is not always the case. Several times in the past few years lightning has struck before contracts can be negotiated.

"We have always had forest fires, but not with this frequency and with this intensity," says wildland firefighter Jeff Spark. With the thousands of hectares of beetle-killed forest, there is plenty of fuel once the lightning strikes. And strike it does. Despite the SW Yukon being in St. Elias's rain shadow, summer thunderstorms are $20 \%$ more likely than they were at the turn of the century, meaning more opportunity for lightning.

The Yukon Forest Management Branch reports that fires used to happen about once every hundred years in a given area. That cycle however is now a historical note.

"From what we have seen in the past 20 years, fires seem to be occurring at shorter, more irregular intervals. For the landscape, this means that spruce trees may not have sufficient time between fires to repopulate areas. Deciduous vegetation like willow and aspen are beginning to dominate the SW Yukon," says Forester Jane Timber, citing the Takhini burn as the most mature example of the new trend.

\section{"It doesn't matter if trees turn to shrubs or shrubs turn to trees. Gold will still be gold."}

The Yukon's response to a changing climate can be characterized as slow at best. Commitments set forth by the Climate Change Strategy (2006) and
Climate Change Action Plan (2009) fell short to spur the government into real action.

A main focus of the government's agenda has been economic growth, largely through an increase of natural resource extraction and exportation, as well as providing the energy to power the growing economy.

"We know the climate is changing and that these changes manifest dramatically on the landscape. But we will not allow it to affect the way companies in the Yukon do business," says Party spokesperson Brad Staunch.

And it hasn't. The economy continues to boom without concern for a future that grows less certain and predictable. They invest and expect reward.

President and CEO of Rocky Mining, Ltd., Arthur Gold says, "It doesn't matter if trees turn to shrubs or shrubs turn to trees. Gold will still be gold."

Some of the biggest changes in the southwest Yukon in the past 20 years have come from the industrial sector, particularly mining. More and more mining claims are changing from exploration to production, and local mineral claims have been increasingly leased to out-of-territory or out-ofcountry companies.

Ten years ago today Rocky Mining, Ltd., an Alberta based company, constructed the Killermun mine and began mining quartz claims west of Killermun Lake within the Ruby Range. Residents of Haines Junction have watched their small town and life, as they knew it, transform over the years.

Helicopter blades chop the air as miners are trafficked to and from Haines Junction 5-6 times daily. Quiet summer sunsets are a thing of the past. 
During time off, miners staying in Haines Junction are often spotted racing speedboats on Pine Lake, beer coolers full and music blaring. For the past nine summers, elders have not cast fishnets in the lake.

The fatal bear attack last year on a miner at the Killermun Mine campsite drove Rocky Mining, Ltd. to institute a "clean camp" policy to reduce the likelihood of bear attacks. Reports by trappers of beer cans left along ATV trails tell the story of the policy's effectiveness. The company's workers who, like the company, come from Alberta seem to lack the same spirit and respect for the natural world that defines a true Yukoner.

As forewarned by the Yukon Conservation Society within the YESAB files, the Killermun Mine has adversely affected wildlife populations. Stripping to uncover quartz veins destroyed natural licks used by sheep and reduced the fragile plants and grasses. Over $100 \mathrm{~km}$ of ATV trails were built, resulting in fragmented habitat and increased access into the previously remote alpine region.

"With all of the commotion from the mine, Dall sheep spent huge amounts of energy being constantly alert. Many of them got weak and became easy targets for wolves," says Conservation Officer Jim Walker.

Consequently, Dall sheep no longer use the area for spring lambing, a fact that Yukon Conservation Society believes to be affecting as many as 300 ewes.

Additionally, the Aishihik caribou herd, which had been recovering in the area as a result of significant management efforts, has not been seen there for several years.
"People have said for years that moose, caribou, and especially sheep are sensitive species. Research was just never clear about how sensitive. Well, now we know," says Alice Munroe, Kluane Region Wildlife Technician.

Mining developments, though invasive, seem to not have affected elk and bison in the same way. Miners report seeing large herds walking new mining roads to travel between habitat patches.

Kluane Lake Outfitters have had to relocate hunting camps on account of the noise and deteriorated wildlife habitat, which has made it harder to find wildlife. The same outfitters report a drop in client satisfaction for guided trips in the area.

Chris Masterson of Kluane Lake Outfitters explains that, "several of his clients mentioned crisscrossing ATV trails making the landscape look less wild." The wild, remote feeling of the landscape is a feature that has been a selling point of outfitting in the Yukon for generations but, as Masterson says, is disappearing.

Similarly, trappers with long traditional family ties to the area have reported significant drops in success along traplines. Champagne and Aishihik First Nation member Mary Agnes also adds, "I would love to run my family's trapline and forget about working a job in the city, but how can I with the price of furs being so low?"

\section{"Coal just makes sense given the pace of new energy demands."}

With the rapidly growing demands on the energy supply, Yukon Energy made the quick decision to embrace coal as a means to rapidly 
increase the amount of energy available to both industry and new residents.

"Coal just makes sense given the pace of new energy demands, "explained Harvey Dam, Communications Supervisor for Yukon Energy back in 2017. When asked why Division Mountain, Dam replied, "The proximity of the Division Mountain coal deposit to the existing electricity grid and its economic feasibility made it an efficient choice for Yukon Energy."

Between 2017 and 2027 Hard Minerals, Ltd. extracted 2.6 million metric tones per year (Mtpy) of coal from an open-pit mine on its Division Mountain properties. Two million Mtpy was washed and shipped to Pacific Rim markets, supplying China with 1.24 million Mtpy of thermal-grade coal. Yukon Energy continues to buy coal from Hard Minerals, Ltd. to supply the local power station (expanded from 50megawatts to 100-megawatts in 2024) that is adjacent to the Division Mountain property.

Though sustainability initiatives took the back seat clean, reliable and affordable coal has helped to triple the territory's 2012 energy production from approximately 400-gigawatts of hydrogenerated power to today's almost 1250gigawatts of mixed hydro and coalgenerated power.

\section{The land-based economy of old dried up as prices and demand for land- based goods plummeted.}

No one is arguing whether or not the territory needs more power. The last 20 years has seen population growth of an average of $7 \%$ per year, resulting in a population of 132,000 for the territory. The $7 \%$ growth rate over the 20 -year span is the highest in Canada.
Much of the population growth can be attributed to a series of industrial booms, the most recent of which has led to yet another influx of out-of-territory workers, many of whom are miners from Alberta the Yukon Bureau of Statistics shows.

More and more people born in the Yukon before the booms are claiming to be "true" Yukoners and feel like a minority. Native Yukoner Clay Johnson says, "Seems like ain't too many people left who were born here. The new people sure think different too. Like everything can and should be blown up."

All the new folks to the territory need housing and developers have scrambled to meet the challenge. Property rates have soared in response. The pressure for housing within commute distance of Whitehorse has transformed the drive along the Alaska Highway between Whitehorse and Haines Junction.

Most notably over the stretch, the Department of Highways and Public Works widened the highway to four lanes in 2018 to eliminate the dangers of commuters passing trucks. A wider road, though, means even higher maintenance costs due to permafrost thawing. Annual repairs are costing upwards of $\$ 30,000 / \mathrm{km}$ of road.

There are also far more turnoffs than there used to be. Recently logged and in many cases agricultural land bordering the Alaska Highway have been converted into high-density subdivisions. The Bratnober and Vanier Subdivisions are examples of new housing within the past 5 years. All 500 lots of the Vanier Subdivision sold the first day on the market.

Space was made for the Vanier Subdivision when Tom Schneider sold 
his farm. "That's the way of it," Schneider says. "You can only stare down that kind of an offer for so long." Jill Farmer, a friend of Schneider's, was surprised he was able to hold out selling as long as he did. "Smart though. 60km from Whitehorse and in this market, he made a killing." It seems only the wealthiest Yukoners have been able to keep the homestead dream alive and ignore the sometimes multimillion dollar offers from real estate developers.

Many smaller towns and communities with long histories are also feeding into Whitehorse's growth. "There used to be 800 people living here. 800!" exclaimed long-time Haines Junction resident Betty Fisk. The Haines Junction population, which for now sits at 3,200, is just close enough for people to make the daily commute to Whitehorse. Not to mention its closeness to Kluane region mining interests.

The population explosion has also coincided with increases in service and sales-related jobs to support a larger population. The Whitehorse Mall opened in 2017 with the slogan of "Tired of shopping online?" Cynthia Shopper says, "It's great! I don't need to fly to Vancouver to shop at the big stores," adding, "Everything is right here in Whitehorse!"

In an effort to fill labor shortages in service positions Yukon Immigration has increased the number of applications through the Yukon Nominee Program. According to the Yukon Bureau of Statistics, during the 2026-2031 census period the Yukon welcomed 1,149 new immigrants, mostly from Asian countries.

The land-based economy of old dried up as prices and demand for landbased goods plummeted. Cabins rot as trappers continue to stay out of the bush. "I think the only ones of us still out here are the ones who are too old to know another way to live," says 65-yr-old Garret "Snare" Hill.

Traps unset, berries unpicked and medicines uncollected. Old activities like these that once gave the Yukon a "last frontier" feel have disappeared, leaving those with the land at heart asking, "Do we have another Yukon to move to?"

This mock-article is part of a study to develop wildlife management based on future scenarios in the southwest Yukon. All names of people and companies within are intended to be fictional. 
Scenario Story Line - S2 - "Slow Boil"

High Cumulative Impacts, Gradual Change, Exploitative

\section{Yukon Herald}

\section{October 11,2032}

\section{Hindsight is 20/20 as Management Fails to React}

According to hunter Simon Caliber it is a frustrating time to be a hunter. "I haven't been able to hunt a caribou or a sheep for several years and now there is a lottery on elk. What's next?!"

Hunting has become a different ball game. During the past seven years, due to the "conservation concerns" provisions of the Umbrella Final Agreement, First Nation members have had hunting priority for caribou, sheep and moose in the southwest Yukon. This has meant that non-First Nation hunters have had to try their luck exclusively with wood bison, elk or deer tags.

That is, until last year.

"We got ourselves into a terrible position by not reacting fast enough," says Karen Chang of Environment Yukon.

"Since the populations of wood bison, elk and deer have remained small there was no choice but to restrict hunting to a permit by lottery system," says Buck Shot of the Hunting \& Trapping Branch.

This year, in addition to a limited hunting season, Environment Yukon in conjunction with Champagne and Aishihik First Nations will be initiating a chemical sterilization program for wolves.

"It may be too late to really help the caribou, moose and sheep in the area but we hope that reducing the growth rate of wolves will spur the growth rate of bison, elk and deer," says Chang.
Though she tried to remain polite, Chang made it clear that if Environment Yukon's budget was even half as large as Energy, Mines, and Resources this problem would not exist.

"We didn't realize [wood bison, elk and deer] populations were so low until the most recent surveys."

Explaining how the southwest Yukon got in this situation can be boiled down to a couple of factors.

Wood bison, elk and deer populations seem to be low as a result of intense hunting, predation, and management without adequate monitoring.

Champagne and Aishihik First Nations Renewable Resource Manager Felix Jackson explains that, "wood bison, elk and deer populations were kept low and contained in order to help the native ungulate species, like caribou."

Kluane Region Wildlife Biologist Leanne Rogers adds that, "We have spent our limited resources monitoring caribou, moose, sheep and predators while surveys of bison, elk and deer populations over the past 10 years have been spotty. We didn't realize that they were so low until the most recent surveys."

Area wildlife managers suspect that since hunting allocations were directed solely at wood bison, elk and deer, their numbers failed to pass 
thresholds where they could continue to grow despite supporting a large harvest.

Wolf predation on bison and elk was low to nonexistent for roughly twenty years after introduction, but once wolves caught on to the new prey source predation increased rapidly.

The increasing predation from wolves, combined with intense hunting pressure and confining management policies has left the wood bison, elk, and deer in their current states.

\section{"Subtle changes to one thing can cause a host of environmental responses."}

Caribou, moose, and sheep populations on the other hand seem to be low more so due to environmental and developmental changes on the landscape.

Environment Yukon's Chang says, "We can see the general year-toyear environmental changes. Over the past 20 years the tundra has slowly receded while the treeline has advanced up mountainsides, particularly on southern slopes. Earlier snow melting, more rapid glacial melt, and permafrost thaw have all contributed to river levels rising. "

These changes, along with temperature increasing slightly, more snow during winters and less rain during summers, represent the southwest Yukon trends.

"The thing is that subtle changes to one thing, like temperature, can cause a host of environmental responses. Everything is so closely linked," explains Chang. "For example, the recent dryness of our summers has decreased the quality of mosses and lichens, forage that caribou prefer. Higher water levels mean that a lot of the willow that moose prefer has been flooded."

Forester Jane Timber tells of how forest succession after fires and pest outbreaks has changed in the southwest Yukon. "Spruce species are not returning like they used to. Just look at the Takhini burn area. It is mainly aspen with a lot of open space and bison, elk and deer are much better suited for that type of landscape."

Understanding how the landscape is changing allows managers to tailor management to the prevailing conditions. The problem is that without the science from proper monitoring, management recommendations seem unfounded.

\section{Increased access into the previously remote alpine region.}

But the larger impact over the past 20 years on caribou, moose and sheep populations in the southwest Yukon has been from development, particularly from the mining industry.

More and more mining claims are changing from exploration to production, and many local mineral claims have been leased to out-ofterritory or out-of-country companies.

Ten years ago today Rocky Mining, Ltd., an Alberta based company, constructed the Killermun mine and began mining quartz claims west of Killermun Lake within the Ruby Range.

As forewarned by the Yukon Conservation Society within the YESAB files, the Killermun Mine has adversely affected wildlife populations. Consequently, Dall sheep no longer use the area for spring lambing, a fact that Yukon Conservation Society believes to be affecting as many as 300 ewes. Additionally, the Aishihik caribou herd, 
which had been recovering in the area as a result of significant past management efforts, has not been seen there for several years.

Examples of mining impacts are stripping to uncover quartz veins, which destroyed natural licks used by sheep and reduced fragile plant and grass cover. Over $100 \mathrm{~km}$ of ATV trails and roads were built, resulting in fragmented habitat and increased access into the previously remote alpine region.

"With all of the commotion from the mine, Dall sheep spent huge amounts of energy being constantly alert. Many of them got weak and became easy targets for wolves," says Conservation Officer Jim Walker.

Kluane Region Wildlife Technician Alice Munroe reveals that, "People have said for years that moose, caribou, and especially sheep are sensitive species. Research was just never clear about how sensitive. Well, now we know."

Mining developments seem to not have affected elk and bison in the same way.

Mining developments, though invasive, seem to not have affected elk and bison in the same way. Miners report seeing herds travel between habitat patches on new mining roads.

"Simply put, wood bison, elk, and deer are better able to adapt to the current circumstances," says Rogers. "At least in the southwest Yukon we need to shift our management focus to these species and talk about range expansion," says Rogers.

Though, the idea of these species expanding their ranges has been a touchy subject for many parties. For example, Kluane National Park and Reserve, managed by Parks Canada, has historically kept its borders closed to animals with lethal force.

"We worry about the bison in particular. We still don't know enough about competition between bison and the native species to let them into the park," explains Gary Park of Parks Canada.

With the management focus having been on containing the newer species to specific areas and population sizes, little new research has been done about impacts - a fact that continues to put many First Nations on the fence about letting the ranges expand into their territories.

\section{People with different values are moving north to fill the vacant jobs.}

The most serious impact on southwest Yukon society has been a result of the expansion of mining projects and the influx of miners.

Even though the province created job training programs to encourage mining companies to hire local Yukoners, there are more available jobs at new mine sites than can be filled by Yukoners alone. This has meant that people with different values are moving north to fill the vacant jobs.

Looking at the impacts of the Killermun Mine on Haines Junction specifically, residents have watched their small town and life, as they knew it, transform over the years. The town has more than doubled in population from the 800 it was 20 years ago.

Helicopter blades chop the air as miners are trafficked to and from Haines Junction 5-6 times daily. Quiet summer sunsets are a thing of the past.

During time off, miners staying in Haines Junction are often spotted racing speedboats on Pine Lake, coolers 
full and music blaring. For the past nine summers, elders have not cast fishnets in the lake.

Reports by trappers of beer cans left along ATV trails tell the story of the company's workers who, like the company, come from Alberta.

"Many of those mining types from down south lack the same spirit and respect for the natural world that defines a true Yukoner," says native Yukoner Clay Johnson.

\section{Only the wealthiest Yukoners have been able to keep the homestead dream alive.}

All the new folks to the territory need housing and developers have scrambled to meet the challenge. The pressure for housing within commute distance of Whitehorse has transformed the drive along the Alaska Highway between Whitehorse and Haines Junction. Property rates have soared in response.

Most notably over the stretch, the Department of Highways and Public Works widened the highway to four lanes in 2018 to eliminate the dangers of commuters passing trucks. Though, in permafrost thawing zones annual repairs are costing upwards of $\$ 30,000 / \mathrm{km}$ of road.

There are also far more turnoffs than there used to be. Recently logged and in many cases agricultural land bordering the Alaska Highway have been converted into high-density subdivisions.

Space was made for the Vanier Subdivision when Tom Schneider sold his farm. "That's the way of it," Schneider says. "You can only stare down that kind of an offer for so long.
$60 \mathrm{~km}$ from Whitehorse and in this market, I made a killing."

It seems only the wealthiest Yukoners have been able to keep the homestead dream alive and ignore the sometimes multimillion dollar offers from real estate developers.

\section{Those subsistence ways are old ways.}

The current circumstances of reduced hunting and human population expansion has reinforced both the need for huge grocery stores like Superstore and the wage jobs that allow people to afford to buy from them.

CAFN's Felix Jackson puts the situation into context. "There aren't enough caribou and moose anymore to hunt those animals alone and you can't rely on getting a hunting tag from the bison or elk lottery. To eat you need to buy groceries. To pay for groceries you need a job. Those subsistence ways are old ways."

Echoing Jackson's sentiments, Hunting \& Trapping's Buck Shot says, "You know, I think it is really only a core group of avid hunters who are upset by the hunting situation. Hunting takes time. A lot more time than walking down a grocery aisle." He adds that, "I think a lot of it also has to do with how people grew up and people moving here from southern provinces may not have grown up with hunting as a way to put food on the table."

\section{"The idea of a 'land-based' economy has reverted to mean mineral extraction, not goods like furs."}

Kluane Lake Outfitters have had to relocate hunting camps on account of the noise and deteriorated wildlife habitat, which has made it harder to find 
wildlife. The same outfitters report a drop in client satisfaction for guided trips in the area.

"Outfitting has become a hard business," says Chris Masterson of Kluane Lake Outfitters. "We can no longer guide for caribou or sheep, which were huge economic drives."

$\mathrm{He}$ adds that, "several of his clients mentioned crisscrossing ATV trails making the landscape look less wild." The wild, remote feeling of the landscape is a feature that has been a selling point of outfitting in the Yukon for generations but, as Masterson says, is disappearing.

Similarly, trappers with long traditional family ties to the area have reported significant drops in success along traplines. Champagne and Aishihik First Nations member Mary
Agnes also adds, "I would love to run my family's trapline and forget about working a job in the city, but how can I with the price of furs being so low?"

Trapper Garret "Snare" Hill adds, "I think the government has forgotten the history of this territory and the activities that truly built it. Non-First Nation people came here for the gold but they fell in love with the land. They hunted and trapped. But the idea of a 'land-based' economy has reverted to mean mineral extraction, not goods like furs. It's a shame."

This mock-article is part of a study to develop wildlife management based on future scenarios in the southwest Yukon. All names of people and companies within are intended to be fictional. 
Scenario Story Line - S3 - "A Confused State"

Low Cumulative Impacts, Unpredictable Change, Stewardship

\section{Yukon Herald $\quad$ - $\quad$ October 11, 2032}

\section{Management Blunders as Managers Learn to Roll with the Punches}

Promises made by the Climate Change Strategy (2006) and Climate Change Action Plan (2009) have come to the forefront of government priority.

Since 2015 all new government buildings have been built to LEED Gold standards. By 2020 greenhouse gas emissions within government buildings were $50 \%$ less than they were in 2010 . Today, all buildings are built on the premise of carbon neutrality.

Every Yukon Government department follows the Green Procurement Policy. When possible they purchase environmentally responsible goods and drive hybrid-electric vehicles.

Premier Alfred Greene's administration even went as far as rewriting codes to prohibit companies without sustainability mandates from operating in the Yukon.

"I am proud to live in a place with a government that embraced the challenges of becoming truly sustainable, especially given the challenges of the climate here," says Yukoner Clay Johnson.

To prepare for climate stresses, several government departments completed risk assessments in 2014 to understand vulnerabilities of infrastructure due to permafrost, water resources, forests, wildlife, and of communities. Yukon Government also implemented extensive monitoring programs in each area that continue today.
"These programs have been expensive, but important expenses," says Premier Alfred Greene.

"When the climate change adaptation tax appeared in 2020 I realized YTG had decided to take their climate change agenda seriously. I gladly pay the tax knowing it's supporting green building and other sustainable initiatives," says homeowner Dan Lenza. "In fact, that leadership is what helped me decide to upgrade to a more efficient wood pulp stove."

The Climate Change Secretariat revamped Yukon Government's climate change education, offering evening workshops on dozens of climate change related topics. Lenza says it was one of those workshops that taught him about wood stove efficiency and other ways to be sustainable at home.

\section{"There is a wealth of mineral resources in the Yukon, but Yukoners are against using the landscape in that way."}

There have been more changes than just new wood stoves and over the past 20 years the mining industry has seen the greatest of these changes. Older, large-scale projects have mostly closed down while new, large-scale projects have been for the most part halted at the feasibility stages.

For example, the Killermun properties within the Ruby Range, which underwent advanced feasibility studies 
in 2012, were held back from production by YESAB due to potential disturbances of Dall sheep spring lambing.

Everywhere in the Yukon, projects are occurring at smaller scales than what plans may have indicated 20 years ago. Massive mining operations, like Casino, never made it past advanced feasibility planning stages.

Mining Lands Officer James Pickett says, "That operation was going to be huge, with a road going right through Carmacks. We were talking 650 employees and a $100 \mathrm{MW}$ power generating station for the mine alone. We were not crazy about what that could do to the area. Can you imagine bringing in that many people from the outside?"

"There is a wealth of mineral resources in the Yukon, but Yukoners are against using the landscape in that way," says Director of Mineral Resources Tony Brock. "That is why right now we are only pursuing smaller, less environmentally disruptive operations."

"There is a line between the kind of farming that is in harmony with the land and the kind that isn't."

Agriculture is another sector that focuses on small-scaled operations.

Jill Farmer says, "With this climate most of what you see are greenhouse-based, family-owned organic farms that aren't very landintensive."

Farmer continues to say that, "there is a huge demand for people to try to eat locally and so hunting is extremely important, but when it comes to supplementing that meat with fruits and vegetables small farming that maintains the health of the soil is important."
Dale Pepper of the Yukon Agriculture Association says, "There is a line between the kind of farming that is in harmony with the land and the kind that isn't. The scale of southwest Yukon agriculture and the sustainable practices keep that balance. Space is left for the wildlife and pesticides are kept out of the watersheds."

\section{After living here, it is not the gold that calls you it's the land's beauty and stillness.}

The words of Robert Service's "The Spell of the Yukon" remind people why a small economy is important. After living here, it is not the gold that calls you it's the land's beauty and stillness.

Chris Masterson of Kluane Lake Outfitters explains that he gets tired of economic arguments for huge resource extraction projects. "Leaving the land the way it is $\underline{i s}$ an economic investment in itself. The wild, remote feeling of the landscape is a feature that has been a selling point of outfitting in the Yukon for generations."

Other Yukoners agree with Masterson. Mary Agnes says, "Keeping mining companies and other industries small is important for trapping. I am excited every day that I wake up knowing I have my family's trapline to stay connected to the land. It's special out there. Always has been, always should be."

Changing environmental conditions have provided avenues for new species of bark beetles to expand north.

But that special place has changed and continues to do so. Rivers flow higher due to melting glaciers while droughts have lasted entire summers. 
Trees move further upslope as the tundra recedes. In many places, aspen has taken over after spruce failed to grow back after fires and beetle kills.

In the past 20 years southwest Yukon forests have been hit more times by bark beetle infestations than ever before in written or oral record. Though not a new threat, spruce bark beetle outbreaks have increased. But what are most worrisome are cases like the 2017 mountain pine beetle outbreak that decimated lodgepole pine in the area.

The outbreak meant that southwest Yukon forests were no longer under assault from the same old pests. Changing environmental conditions have provided avenues for new species of bark beetles to expand north.

In 2018 the Yukon Forest Management Branch responded with an intensive proactive management regime. They brought in Fire Cuts, a company from British Columbia that specializes in sustainable selective harvesting techniques, to harvest small patches of dead and stressed, dying trees. Yukon Energy then buys the harvested trees to supply a wood pellet burner.

From a forest management perspective, "the selective harvesting regime was intended to serve many purposes. Removing dead and dying trees would control stress on trees due to dry summers, remove forest fire fuel loads, and help reduce the number of susceptible hosts for beetles," says Jane Timber of the Yukon Forest Management Branch. She added, "Ideally we wanted to prevent largescale beetle outbreaks and forest fires by promoting healthy trees."

Regarding the wood pellet burner, Dan Burns of Yukon Energy says, "We realize that there are emissions from burning the wood pellets and that people were upset at the decision to burn wood pellets as an energy source. But from a sustainability standpoint we felt that wood pellet emissions are less of an environmental impact than diverting and ultimately flooding the Gladstone Lakes system for additional hydro capacity at our Aishihik facility."

Yukon Energy Communications Supervisor Harvey Dam says, "We wanted to look more into geothermal energy, but with the unpredictable changes to permafrost and how that is affecting our aquifers; it just isn't stable right now."

One of the tempting aspects of the wood pellet energy project was the ability of Yukon Energy to sustain it. "Not including beetle-killed wood, harvesting and replanting an eight square kilometer area of forest is all the energy we need to run a one-megawatt generator indefinitely, or enough to power about 1000 homes," Burns says.

But not all plans work as intended. Thinning out forests made them more susceptible to wind, which in itself increases a forest's susceptibility to fire. Not to mention, "thinner forests alter habitat dynamics for wildlife and may have contributed to the decreasing caribou and moose populations, while at the same time aiding wood bison, elk and deer by opening up forests and creating small meadows," says Kluane Region Wildlife Biologist Leanne Rogers.

Unintended consequences and high expense, low result management seemed to be a common thread.

In the ten years between 2012 and 2022, unintended management consequences and high expense, low 
result management seemed to be a common thread.

Worried about low numbers of caribou and moose, wildlife managers felt pressured to reach back to the 19921997 Aishihik wolf control plan. This time, managers exclusively used sterilization techniques to control wolf numbers with the hopes that reducing wolf numbers again would help caribou and moose calves survive to adulthood.

In the narrow scope of the plan, managers forgot about potential affects to the "newer" ungulates. Rogers admits that, "We forgot about bison, elk and deer. The first time we controlled wolves with management they weren't really an issue. With reduced predator pressures elk, deer and even wood bison populations exploded. We didn't realize how much wolves were controlling these other species."

Ultimately, The Department of Wildlife \& Biodiversity spent huge portions of its operating budget on caribou, moose and sheep management trying to keep their populations viable. But, "at a certain point," Rogers says, "nothing you do will elevate caribou populations if their habitat requirements are disappearing."

Prioritizing some species over others has real impacts on species of less priority. For example, in the summer of 2028, CAFN hunter Felix Jackson reported finding several aborted wood bison fetuses to his Renewable Resource Officer. The fetuses were tested and confirmed to be infected with brucellosis by The Animal Health Unit at Environment Yukon.

"I figured there must've been something wrong with 'em if a bear didn't eat 'em," observed Jackson.

"Brucellosis is a concern because of its transferability to humans and animals," says wildlife veterinarian Angela Bovine, "and could pose a threat to the herd's viability if it goes untreated."

The appearance of the disease raised several questions that have yet to be fully answered. Where did it come from and are other diseases present in the bison or elk herds that we might have missed because wildlife managers did not monitored closely enough?

In the future anthrax outbreaks, which killed 400 wood bison in the Mackenzie Bison Sanctuary in the Northwest Territories in 2012, could become a problem considering how the sw Yukon area recently has seen flooding and subsequent droughts, conditions that promote increased concentrations of anthrax spores.

Timber says it is a difficult time to be a resource manager. "We try to be proactive with resource management whenever possible, but with how fast and unpredictable things are these days we are often forced to react. You can't plan for animals falling through thin ice, freak blizzards, or prolonged summer droughts."

Because of these past management blusters, resource managers have had to take a hard look at management tactics in the face of abrupt and unpredictable changes. Environment Yukon's Karen Chang says, "We accept that what is happening is beyond our ability to control with management. We can't repeat past mistakes."

Rogers adds that, "From a wildlife perspective this means pulling some of the resources for species that were intensively managed in the past, such as caribou, and directing them towards improved monitoring programs geared towards landscape resilience and species that are doing well with the 
environmental changes, such as bison and elk."

According to Rogers, this is especially necessary considering that "research reports coming in are often outdated by the time they are read, so it is hard to plan management on science that may have in fact already changed.

"Then, it is difficult to even reactively manage when you have to budget money in March for the entire upcoming year. Money runs out." When this happens Rogers says that her office adopts a "roll with the punches" attitude. However, in recent years it has become the attitude.

Initially decisions to shift management priorities were not popular with the public. But both Environment Yukon and First Nations governments in the southwest Yukon agree that management has to be directed where it can be effective.

"Management has changed to focus more on resilience of the landscape," says Chang. "To achieve this we are promoting cooperation between departments."

Rogers says, "Limiting nonclimate stressors is the best thing we can do for the Yukon's wildlife. We have worked with Energy, Mines, and Resources to reforest unused logging roads and looked at ways to reduce pollution and erosion from mining operations."

\section{"People slowly realized that there are other animals that can fill a freezer."}

\footnotetext{
Reevaluating values has gone beyond resource management to Yukoners in general. As populations of caribou, moose, and sheep dwindled, people began to appreciate wood bison, elk, and deer.
}

"Those of us with our eyes on the land could see the changes to the wildlife," says Champagne and Aishihik First Nations trapper Mary Agnes. "We just don't have the same cultural ties to those elk and bison that seem to be everywhere."

Agnes says that it took her a long time to begin appreciating wood bison especially. "A few years back they ruined a cabin on my trapline and their yellow fat still grosses me out. If the disease issue isn't contained, that could be a real problem. But better a bison to hunt than nothing."

Statements like this represent the swing in opinion that gripped many Yukoners through the past 20 years. Hunter, Simon Caliber, reflects that it was pandemonium when conservation concerns provisions of the UFA were implemented for caribou, moose, and sheep in 2025.

"People acted like there was some huge crisis. But like everything it faded. I think people slowly realized that there are other animals that can fill a freezer," Caliber says and adds, "To be honest, elk is the best eating out there."

Garret "Snare" Hill explains that he is just happy that he can continue living off of the land. "It is harder than before," He says. "You don't know whether your piece of the forest will be there come the morrow, but that's part of the thrill, isn't it?"

This mock-article is part of a study to develop wildlife management based on future scenarios in the southwest Yukon. All names of people and companies within are intended to be fictional. 
Scenario Story Line - 4 - "Win-win"

Low Cumulative Impacts, Gradual Change, Stewardship

\section{Yukon Herald $\quad$ - $\quad$ October 11, 2032}

\section{Management Looks to Future as it Adapts to Slow Change}

Premier Alfred Greene explains that his government's goal is to "create and maintain a place to live that avoids the unstable boom and bust cycles of so many economies. One way we sought to accomplish this was to focus our economy and energy systems on sustainable solutions. This government understand that we humans are just one part of the system, and its functioning depends on us not abusing our place in it."

The Premier was not just politicking with that statement. Since 2015 all new government buildings have been built to LEED Gold standards. By 2020 greenhouse gas emissions within government buildings were $50 \%$ less than they were in 2010. Today, all buildings are built on the premise of carbon neutrality. Additionally, every Yukon Government department follows the Green Procurement Policy.

\section{Yukon Energy committed to green, renewable energy solutions.}

Around 2016, Yukon Energy committed to green, renewable energy solutions and decided to be a model for the rest of Canada as a way to move forward in answering energy demands. Recognizing that the Yukon lies on significant fault lines, geothermal energy production was a no brainer.

In 2017 Yukon Energy commissioned a geothermal feasibility study for the southwest Yukon by Genergy, Inc. The study showed high potential for ground water heating pumps in Haines Junction, Carmacks, Burwash, and parts of Whitehorse.

Since 2019, local municipalities have been installing geothermal heat pumps in buildings, reducing emissions from heating and cooling by up to $94 \%$.

"Geothermal heat pumps are very energy efficient. They produce three to four times as much heat energy as they use and can heat or cool buildings depending on the outside weather," says Yukon Energy Communications Supervisor Harvey Dam.

Yukon Energy hopes to make geothermal heating available to singlefamily homes soon. Until then, they encourage efficient wood pulp burning stoves. "A lot of wood after beetle kills or fires is salvageable and is a valuable heat source," says Dam.

Even though hydropower is clean many people are uncomfortable with the impacts when a dam is erected at a new location.

Yukon Energy looked hard into the Gladstone Diversion Concept, a plan that would reverse the flow of Gladstone Creek and send the water through a canal into the Isaac Lakes. The plan would have likely caused water levels to rise and for some of the Gladstone lakes to merge.

Harvey Dam says, "The project would increase the capacity of our Aishihik Hydro Facility by 18 gigawatt 
hours of power per year, but people aren't interested in seeing those kinds of changes on the landscape."

Geothermal is clean and avoids environmental impacts like flooding valleys. Yukon Energy's one concern is the long-term viability of geothermal. It is possible that in the future permafrost thaw could disrupt the geothermal reservoirs. For now, though, it is still a good solution.

\section{"Understanding how the landscape is changing allows us to tailor management to those conditions."}

Future changes, like those to permafrost, are of high concern to Yukoners. Karen Chang of Environment Yukon says, "We're pretty lucky. Things are changing fast enough that we can tell change is happening and how, but not so fast that we can't adapt management."

In 2014 Yukon Government, First Nations governments, and various university research teams collaborated to complete risk assessments to understand vulnerabilities of infrastructure due to permafrost, of water resources, of forests, of wildlife, and of communities.

The partnerships also worked to implement an overarching "Eyes on the Land" monitoring program. The program continues today and has focused on areas from the risk assessments.

"This program has been expensive, but an important expense," says Premier Alfred Greene. "University contributions to research in the southwest Yukon has ben invaluable."

Chang says, "The monitoring programs have enabled us to see year-toyear changes on the landscape. Over the past 20 years the tundra has slowly receded while the treeline has advanced up mountainsides, particularly on southern slopes. Earlier snow melting, more rapid glacial melt, and permafrost thaw have all contributed to river levels rising."

According to Chang these changes, along with temperature increasing slightly, more snow during winters and less rain during summers, represent the southwest Yukon trends. "Understanding how the landscape is changing allows us to tailor management to those conditions."

Kluane Regional Wildlife Biologist Leanne Rogers explains that, "caribou and moose have been slowly declining over the past 20 years but with the knowledge gained from the monitoring programs huntable numbers have been successfully maintained."

Through monitoring it was learned that predation pressure on caribou and moose from wolves was extremely high. In response Environment Yukon began a chemical sterilization program for wolves and an incentive program for trappers, granting small subsidies for wolf or coyote furs.

\section{Wood bison, elk, and deer have not struggled under changing conditions.}

Unlike caribou and moose, wood bison, elk, and deer have not struggled under changing conditions. Wood bison and elk, which were reintroduced, have thrived and their populations have been heavily restricted to their original areas of reintroduction.

Champagne and Aishihik First Nations Renewable Resource Manager Felix Jackson says, "Allowing wood bison or elk to expand beyond their current ranges would require other First Nation governments to manage them. Our resources should be directed at the 
native species that are important to us culturally."

Finances are only one reason for constraining elk and bison expansion.

"There is less and less quality habitat for caribou and moose. Forage quality, especially of mosses and lichens, has decreased with the dry summer conditions. We want to keep wood bison and elk off of what good habitat remains to reduce possible competition," says Jackson.

Parks Canada maintains the same stance with regards to wood bison and elk and continues to keep its borders closed to the animals with lethal force.

Despite the present focus of management on preserving native species, managers are not blind to the truth of current trends.

Kluane Regional Wildlife Biologist Leanne Rogers says, "More and more habitat patches are being created that favor wood bison, elk, and deer. Trees are dying one way or another, from fire, insects, or drought and this is opening up the forests."

Other worries are about major events and the response of the southwest Yukon landscape.

"We have had the occasional fire and beetle outbreak over the past 20 years. Nothing unusual about that," says Jane Timber says. "What is different is forests aren't coming back like they used to after major disturbances. Aspen mostly succeeds like after the Takhini burn, but in some cases it has turned to steppe."

\section{"The yellow fat still freaks me out, but I have bison in my freezer."}

Forward thinking about the possibility of habitat converting to favor some species over others has definitely built tolerance for wood bison, elk and deer within wildlife management circles. For other Yukoners, even with the present lack of cultural significance and the worry of competition with other animals, the newer ungulates seem to be on the landscape to stay.

"They are valuable species for their ability to remove hunting pressure from caribou and sheep," says Chris Masterson of Kluane Lake Outfitters. "Sheep and caribou are popular Big Game animals and bringing people to hunt them is an important part of the economy, whereas someone looking for meat for their freezer is often happy with an elk."

Time is another factor for Yukoners with wage jobs that validate bison, elk and deer.

"Most times when I hunt I only have a day or two to bag an animal. It can be hard to find a caribou, moose, or sheep in that time. But elk, I can find a whole herd of elk walking on the side of the road," says hunter Simon Caliber.

But for people living on the land, bison can be disruptive. Mary Agnes says, "Bison have wrecked entire traplines of my family's before, have rubbed against my cabin, and don't even talk to me about muskrat push-ups. There is one area close to a trapline of my family's that bison use to wallow every summer. There used to be willow there with moose but now it is just open mud and grass."

When asked if she eats bison Agnes said, "The yellow fat still freaks me out, but I have bison in my freezer. I like to make smokies out of "em."

One thing that outfitters, hunters, and trappers alike have in common is the appreciation for their opportunities to engage with the land. 
Agnes says, "I love to live in my cabin through the winter, eating what I have hunted and gathered and checking my traplines."

She adds that there are few places left in the world where you can live entirely from the land in this way, but get into town if you need something and buy it from a locally owned store rather than a chain.

\section{In the mining industry, large projects have mostly shut down in favor of smaller operations.}

The repulsion of many national chain companies within the last 10 years well defines the attitude of southwest Yukoners.

"People boycotted stores without proven environmental records," says Whitehorse resident Cynthia Shopper. "And some of the bigger stores, like Supergrocery, were just so big and impersonal. Who wants to shop at a place where you can't see the people that it benefits?"

Smaller development seems to be a trend in other areas of the economy as well. In the mining industry, large projects have mostly shut down in favor of smaller operations.

For example, the Killermun properties within the Ruby Range, which underwent advanced feasibility studies in 2012, were held back from production by YESAB due to potential disturbances of Dall sheep spring lambing.

Everywhere in the Yukon, projects are occurring at smaller scales than what plans may have indicated 20 years ago. Massive mining operations, like Casino, never made it past advanced feasibility planning stages.

Mining Lands Officer James Pickett says, "That operation was going to be huge, with a road going right through Carmacks. We were talking 650 employees and a 100MW power generating station for the mine alone. We were not crazy about what that could do to the area. Can you imagine bringing in that many people from the outside?"

"There is a wealth of mineral resources in the Yukon, but Yukoners are against using the landscape in that way," says Director of Mineral Resources Tony Brock. "That is why right now we are only pursuing smaller, less environmentally disruptive operations."

\section{After living here, it is not the gold that calls you it's the land's beauty and stillness.}

Agriculture is another sector that focuses on small-scaled operations.

Jill Farmer says, "With this climate most of what you see are greenhouse-based, family-owned organic farms that aren't very landintensive."

Farmer continues to say that, "there is a huge demand for people to try to eat locally and so hunting is extremely important, but when it comes to supplementing that meat with fruits and vegetables small farming that maintains the health of the soil is important."

Dale Pepper of the Yukon Agriculture Association says, "There is a line between the kind of farming that is in harmony with the land and the kind that isn't. The scale of southwest Yukon agriculture and the sustainable practices keep that balance. Space is left for the wildlife and pesticides are kept out of the watersheds."

The words of Robert Service's "The Spell of the Yukon" remind people why a small economy is important. After 
living here, it is not the gold that calls you it's the land's beauty and stillness.

This mock-article is part of a study to develop wildlife management based on future scenarios in the southwest Yukon. All names of people and companies within are intended to be fictional. 